\title{
12 Prescribed Fire in Industrial Pine Plantations
}

\author{
C. DE RONDE ${ }^{1}$, J.G. GOLDAMMER ${ }^{2}$, D.D. WADE ${ }^{3}$, and R.V. SOARES ${ }^{4}$
}

\subsection{Introduction}

Industrial plantations of non-indigenous tree species (exotics) can be defined as even-aged stands established outside of their natural habitat. These plantations play a vital economic role in the developing countries of the tropics and subtropics. The ecological benefits of afforestation, however, go far beyond local and regional considerations: the increase in atmospheric $\mathrm{CO}_{2}$ and its expected negative influence on the global climate may partially be averted through large-scale afforestation with fast-growing species (Maryland 1988). The take-up of carbon in woody matter could potentially balance the discharge of $\mathrm{CO}_{2}$ from fossil fuel burning and from the vast amount of uncontrolled forest destruction and biomass burning in the tropical and subtropical biota. Although prescribed burning is itself an emission source of $\mathrm{CO}_{2}$, its main function in plantation management is to increase stability and to protect against destructive wildfires, which are a much larger source. The same is true for particulate matter emissions. Thus, although at first glance it may seem contradictory, prescribed burning is indeed an important link in global fire ecology.

Of the estimated 9,968,000 ha of industrial plantations established in the tropics by the end of 1985, $41 \%$ were in softwoods (mainly pines) (Table 1).

Even though almost $60 \%$ of the industrial plantations are composed of hardwoods such as eucalypt and teak, most prescribed burning has taken place in pine stands. This chapter will thus be restricted to a discussion of fire in pine plantations. The information needed to plan and safely conduct prescribed fires beneath standing trees (referred to as underburning) and the ecological effects of these fires will be emphasized. The importance of fuel and weather parameters is explained, and techniques of setting fires and monitoring their behavior are described. Some facets of post-harvest burning are also discussed.

The major species used in pine afforestation activities are Pinus caribaea, $P$. elliottii, $P$. patula, $P$. Pinaster, $P$. radiata, and $P$. taeda. According to McDonald and Krugman (1986), the leading species are $P$. elliottii and $P$. taeda. They estimate that over 450,000 ha are planted to these two species outside their native

\footnotetext{
${ }^{1}$ Saasveld Forestry Research Centre, South African Forestry Research Institute, George 6530, South Africa

${ }^{2}$ Department of Forestry, University of Freiburg, 7800 Freiburg, FRG

${ }^{3}$ Southeastern Forest Experiment Station, USDA Forest Service, Dry Branch, Georgia 31020, USA

${ }^{4}$ Department of Forestry, Federal University of Paraná, 80.001 Curitiba, Paraná, Brazil
} 
Table 1. Areas of established industrial plantations (in thousand ha) in 76 tropical countries (estimated/projected at the end of 1985). (FAO 1982)

\begin{tabular}{|c|c|c|c|c|c|c|c|c|}
\hline \multirow[b]{3}{*}{ Region } & \multicolumn{4}{|c|}{ Hardwood species } & \multicolumn{4}{|c|}{ Softwood species } \\
\hline & \multicolumn{2}{|c|}{$\begin{array}{l}\text { Other than } \\
\text { fast-growing }\end{array}$} & \multicolumn{2}{|c|}{ Fast-growing } & \multicolumn{2}{|l|}{ Species } & \multicolumn{2}{|c|}{ All species } \\
\hline & Total & $1981-85$ & Total & $1981-85$ & Total & $1981-85$ & Total & $1981-85$ \\
\hline $\begin{array}{l}\text { Tropical America } \\
\text { ( } 23 \text { countries) }\end{array}$ & 183 & 54 & 1393 & 525 & 2403 & 832 & 3979 & 1411 \\
\hline $\begin{array}{l}\text { Tropical Africa } \\
\text { ( } 37 \text { countries) }\end{array}$ & 414 & 121 & 232 & 70 & 673 & 132 & 1319 & 323 \\
\hline $\begin{array}{l}\text { Tropical Asia } \\
\text { ( } 16 \text { countries) }\end{array}$ & 2137 & 324 & 1560 & 477 & 973 & 367 & 4670 & 1168 \\
\hline $\begin{array}{l}\text { Total } \\
\text { ( } 76 \text { countries) }\end{array}$ & $\begin{array}{l}2734 \\
=27 \%\end{array}$ & 499 & $\begin{array}{l}3185 \\
=32 \%\end{array}$ & 1072 & $\begin{array}{l}4049 \\
=41 \%\end{array}$ & 1331 & 9968 & 2902 \\
\hline
\end{tabular}

range each year. Fire plays a predominant role in the native habitats of all the above species. Because these species have evolved in close association with fire, they have developed adaptations that make them better able to survive frequent fires than are competing woody species. The dynamic ecological equilibrium maintained by fire thus favors development of pine-dominated stands. Furthermore, in most cases exotic plantations are established in fire-prone environments or even in fire ecosystems (e.g., in savannas, grasslands, fynbos etc.). When pines are planted in such areas, attempting to exclude fire is counterproductive. The resulting unnatural accumulation of litter substantially increases the potential of destructive wildfires and retards formation of a herbaceous/woody understory component necessary for ecological stability.

The information presented in this chapter comes mainly from Australia, South Africa, and the United States, where most of these species are extensively planted and where fairly intensive fire research has been carried out. The intentional use of fire to help manage these plantations is perhaps exemplified in the southern United States, where over 1.5 million hectares of southern pine are treated with prescribed fire each year (Wade and Lunsford 1989). Prescribed burning experiments have been carried out in many tropical and subtropical countries including Bahamas, Belize, Brazil, Costa Rica, Fiji, Honduras, Nicaragua, Panama, Spain, and Venezuela, but there are few instances where the practice is currently operational (e.g., Fahnestock et al. 1987; Munro 1966; Vega et al. 1983). Nonetheless, these studies have in many cases demonstrated that prescribed fire can be safely and effectively used in industrial plantations. Used under the wrong conditions, however, prescription fire can destroy the very resource it was intended to protect, and there are trade-offs associated with every fire that should be recognized and carefully weighed before a decision is made regarding the use of fire. This does not mean, however, that its use should be summarily dismissed. 
In many instances prescribed fire can achieve planned benefits at minimum damage and cost in comparison to alternative treatments. Although many specific questions remain to be answered, long-term studies in the southern United States suggest that the benefits of prescribed fire far outweigh any deleterious side effects provided the burns are properly conducted. It is generally agreed that the use of fire greatly facilitates the task of maintaining the overall stability and productivity of fire-climax (pine) forests and in many cases is more environmentally acceptable than are mechanical or chemical means of achieving the same objective.

\subsection{Prescribed Burning Objectives}

The reasons for using prescribed fire in pine plantation management are fairly universal (see Table 2) although implementation of this practice will vary by species and from country to country. The specific reason(s) for treating an area with fire should be identified and clearly defined in a written fire management plan. This will not only facilitate assessment of the various weather, fuel, and firing technique combinations that will produce the desired fire behavior, but it will allow meaningful comparison of alternative treatments. One of the advantages of prescription fire over many of its alternatives is that a single application can produce multiple benefits. For example, on the coastal plain of the southern United States, the judicious use of fire can enhance range, wildlife, and timber management objectives on a single area to the extent that the net economic return from this combined effort will be greater than if the land was managed exclusively for a single resource (Wade and Lewis 1987).

\subsubsection{Wildfire Hazard Reduction}

From an economic standpoint, the most important use of prescribed fire in plantation management is to temporarily reduce the hazardous build-up of dead fuels on the forest floor. Prescribed fire is the only practical way to reduce the dangerous accumulation of combustible fuels underneath industrial pine plantations and this, in turn, dramatically reduces the risk of damaging wildfire. These fuels rapidly accumulate, tying up large amounts of nutrients in decomposing organic matter. Fire is nothing more than rapid oxidation of plant matter, the same basic process as decomposition, albeit it takes place at a considerably faster rate. A well-planned low-intensity prescribed fire every 2 to 4 years reduces these fuels and recycles the nutrients into a form useable by the trees. McArthur (1971) states that severe fire suppression difficulties in coniferous plantations should not develop if fuel loads are kept below $11 \mathrm{t} \mathrm{ha}^{-1}$. Studies invariably show that wildfires which burn into areas where fuels have been recently reduced by prescribed burning are much easier to control and cause less damage (e.g., Davis and Cooper 1963; Helms 1979). The interval 


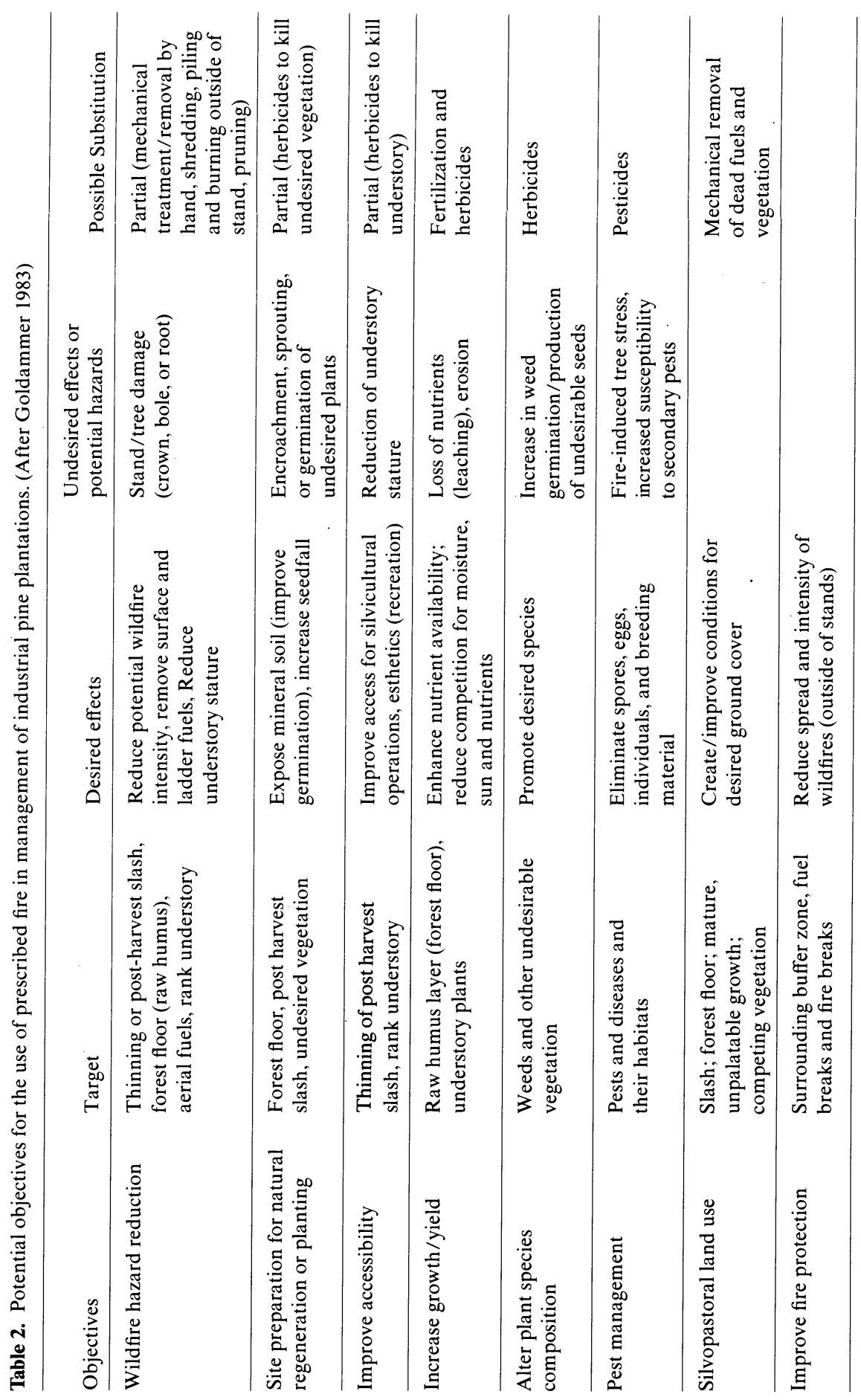


between fuel reduction burns depends on several factors including species, the rate of fuel accumulation, values at risk, and the risk of wildfire. The initial hazard-reduction burn in a young stand should always utilize a backing fire under exacting weather conditions. This initial burn is more difficult to implement in some species, $P$. caribaea in particular, because it retains dead stem needles for a considerable period of time, creating a high potential for "torching out". Luckily, this species can withstand fire intensities of $6900 \mathrm{~kW} \mathrm{~m}^{-1}$ (a factor of 10 above most other pines) without suffering severe mortality (McArthur 1971).

In some instances, prescribed burning by itself will not fireproof a plantation. In Australia, for example, McArthur (1971) reported that fire control was hopeless in pine plantations which were not pruned. He refers to studies which show that fire rate-of-spread is at least double and suppression difficulty is increased by a factor of 4 or 5 in unpruned plantations. He therefore states that pruning is a basic requirement of sound plantation fire management, irrespective of the use of prescription fire.

\subsubsection{Prepare Sites For Planting}

After harvest, unmerchantable limbs and stems remain scattered across the area, or concentrated at logging decks or delimbing gates, depending upon the method of logging. A high percentage of a site's nutrient capital is locked up in this debris. This material is also an impediment to both people and planting equipment. Moreover, if a wildfire occurs within the next few years, fireline construction can be severely hindered; the result being larger burn acreages and higher regeneration losses. Prescribed fire is often used to reduce this debris; although not all large material will be consumed, what is left is exposed and can be avoided by equipment operators.

\subsubsection{Other Objectives}

Cattle grazing can be compatible with good plantation management providing cattle numbers are kept in balance with forage yields. The reduction in, and compaction of, fine fuels which help protect the plantation from damaging wildfires is an added benefit. Grazing is profitable from soon after when a site is planted until the herbaceous component is shaded out as the plantation matures. Prescribed fire is often used in conjunction with grazing to increase the quantity, quality, availability, and palatability of grasses and forbs. McArthur (1971) reports that in Australia and the Fiji Islands, grazing results in the replacement of low-quality tussock grasses with a more palatable creeping type of grass.

Even with intensive site preparation, competing woody vegetation often becomes re-established very quickly. Where these woody plants form a dense shade-tolerant understory, periodic burns will topkill the underbrush, limiting 
competition with the crop trees while at the same time providing succulent browse for wildlife. Keeping the stature of the understory low improves the efficiency of subsequent silvicultural operations and provides greater safety for woods workers. The improved visibility and accessibility can increase stumpage values. Hiking, hunting, and other recreational uses also benefit.

The fact that understory control can improve crop tree productivity is well established (e.g., Haywood 1986; Stewart et al. 1984). However, when using prescribed fire to control competing vegetation, the results are not as clearcut. Intuitively, the increase in available water and the more rapid recycling of nutrients should stimulate growth of the crop trees, but study results documenting reduced growth after low-intensity prescribed fires have been reported (Boyer 1987; Zahner 1989). Other studies show increased crop tree growth even after obvious crown damage (Johansen 1975). A strong possibility is that burning under conditions of low soil moisture results in the death of many feeder roots. Threshold moisture levels are currently unknown, but the problem can be minimized by burning only under high soil moisture conditions and by utilizing weather and firing techniques that will ensure some of the forest floor remains. Crow and Shilling (1980) give an excellent summary of the use of prescribed fire to enhance pine timber production in the southern U.S.

The ecological shortcomings and potential risks associated with extensive areas of pine monoculture are well recognized. Goldammer (1982) suggests that prescribed burning can dramatically reduce some of these risks and shortcomings, thereby helping to stabilize these plantations ecologically. Reducing the heavy accumulation of litter allows an understory of herbaceous and woody vegetation to become established, thereby increasing biodiversity of the area. Establishing a hardwood understory in pine plantations in the Federal Republic of Germany resulted in a reduction of insect pests (Luedge 1971). Craighead (1977) recalled the original forest insect damage survey in California, U.S.A., where much lower bark beetle losses were observed on prescribed burned areas than on unburned lands. Weaver (1959) noted the same situation in Oregon, U.S.A., where bark beetle populations were endemic on an old burn but epidemic in the surrounding unburned forest. Hedden (1978) stated that the only practical way to reduce the risk of southern pine beetle (Dendroctonus frontalis) in the southern U.S.A. was to practice intensive forest management, including the use of prescribed fire.

\subsection{Fuel Appraisal}

Although pine plantation fuels are relatively homogeneous (Fig. 1), they can still vary considerably within a plantation and especially between plantations, depending upon such factors as natural vegetation patterns, species planted, and inherent site productivity, to name a few. Fuels also change over time as a plantation ages and in response to stand-tending measures. Because fuel appraisal is such an important prerequisite to accurate fire behavior prediction, 


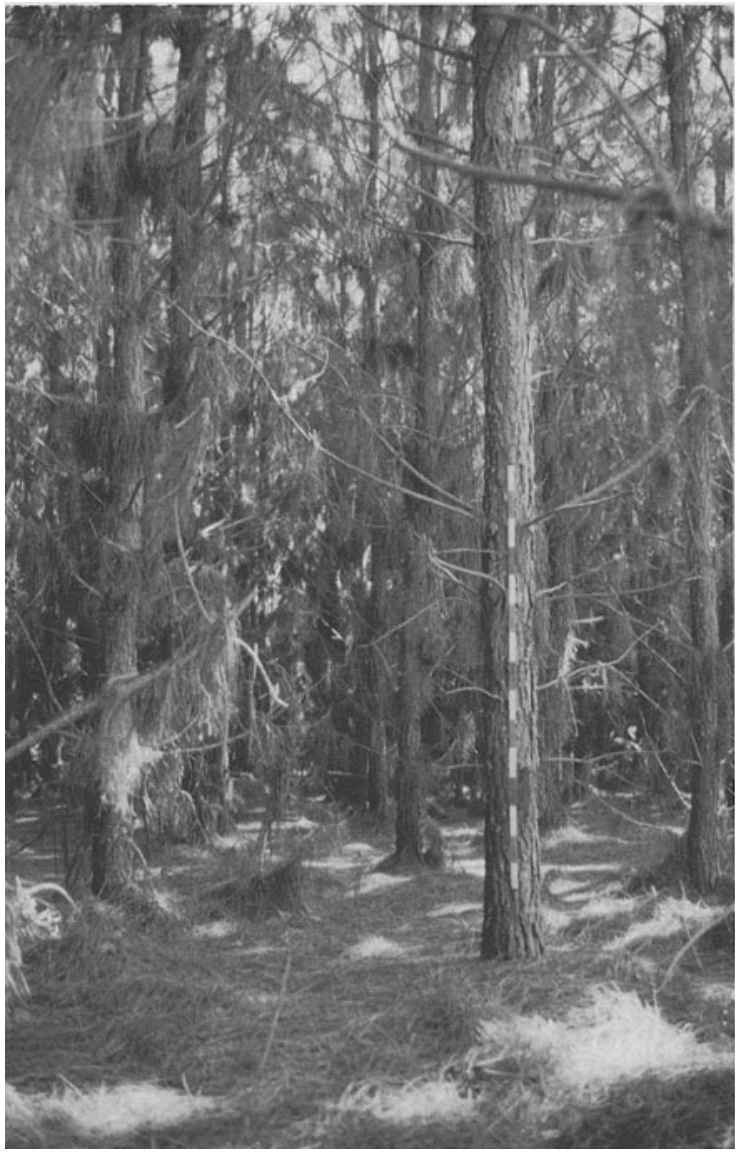

Fig. 1. A typical fuel load of undecomposed needles in a 9-year-old P. elliottii stand. Note the lack of understory and the ladder (aerial) fuels. Fazenda Monte Alegre, Klabin do Paraná, Brazil (April 1981).

a fuel classification and mapping system should be developed for your management area (Fig. 2). Site-specific knowledge of the complexity and spatial distribution of fuels is needed for many other fire management tasks as well, such as in fire-danger rating and to determine initial attack responses to wildfire.

\subsubsection{Natural Vegetation}

After planting, herbs and other early successional plants tend to rapidly dominate a site. By the second year, woody vegetation generally becomes well established and competes with the pine seedlings for sunlight, water, and other nutrients. Many of these species are light-intolerant and are shaded out as the pine canopy closes with age. Some species, however, persist and eventually form a dense understory. A forest floor begins to form as litter accumulates from the 
Fig. 2.Use of the planar intersect technique for assessing the surface fuel load in a 15-year-old $P$. taeda plantation after third thinning. Fazenda Monte Alegre, Klabin do Paraná, Brazil (October 1982)

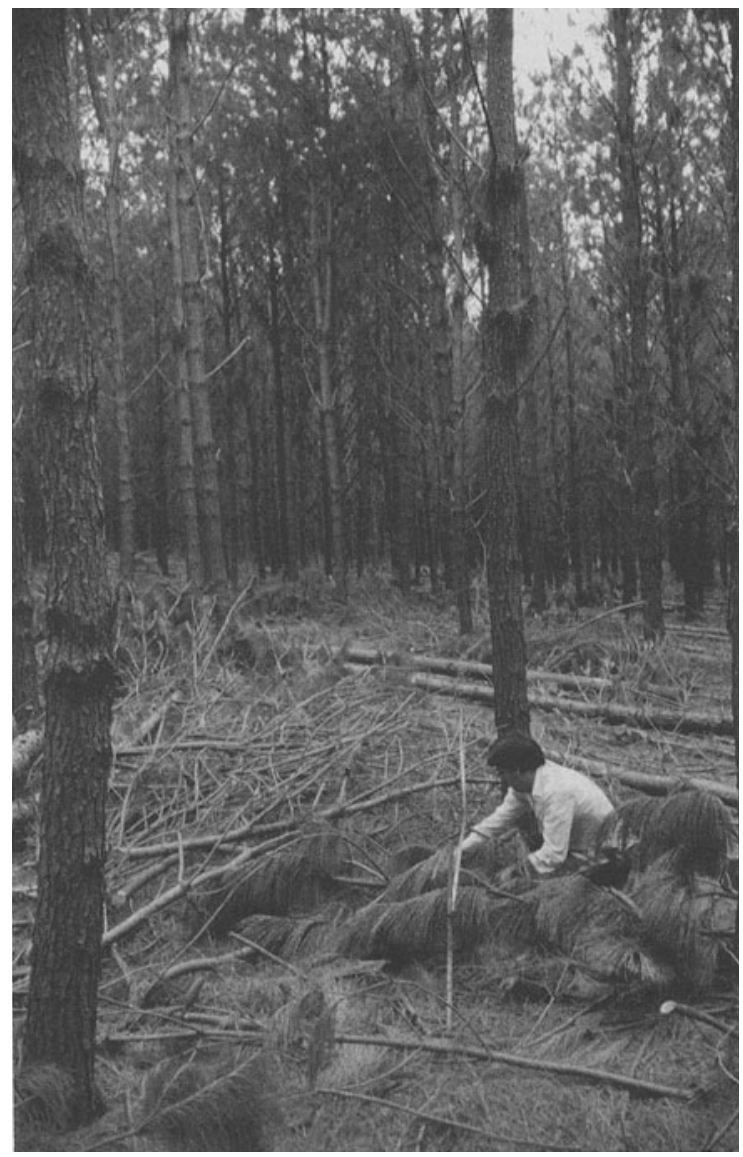

annual needlefall. This build-up of dead fuels continues until the rate of decomposition approximates that of accretion and a dynamic equilibrium is reached. Cultural practices such as thinning and/or pruning can add significant amounts of flammable debris. The burnable fuels on a site make up the total fuel complex. This total is called the fuel loading and is expressed as an ovendry weight on a per unit area basis. Large-diameter living stems are generally not included in fuel loading estimates, although they can be. That portion of a fuel load that would actually be consumed under specified burning conditions is called available fuel.

\subsubsection{Available Fuel}

The amount of fuel that is available under a given set of burning conditions depends upon the prevailing weather (mainly wind and relative humidity) fuel 
parameters (such as size, shape, moisture content, arrangement, and continuity), slope, and the intensity of the fire itself.

To help estimate available fuel, the fuel load is often partitioned into the categories of live and dead because moisture levels in living plants are primarily controlled by life processes while those in dead fuels are dictated by the weather - mainly precipitation, relative humidity, and temperature. A further distinction is often made between surface and aerial fuels.

\section{Underburning}

The quantity of readily burnable fuels on the forest floor is one of the most important factors in determining the rate of spread and intensity of a fire. Even though decomposition tends to be fairly rapid in the tropics, growth in industrial pine plantations is also very rapid and a thick litter layer develops (Goldammer 1982). Prior to crown closure, the herbaceous plant cover prevents the sloughed needles from forming a flat compact bed; instead, these needles and twigs remain partially elevated in jack straw fashion producing an extremely flammable fuel bed several decimeters deep. Thickness of the litter layer varies with species and with site parameters. For example, Schutz (1987) found the minimum litter depth was the same $(3 \mathrm{~cm})$ under stands of $P$. patula, P. elliottii, and $P$. taeda in the Eastern Transvaal, but the average $(10 \mathrm{~cm})$ and maximum $(35 \mathrm{~cm})$ depths under $P$. patula were about twice that of the other two species. He also found that litter thickness increased with altitude and wet soil conditions and decreased as site index increased. The number of stems per hectare had little effect once crown closure had taken place.

Aerial fuels with the most influence on fire behavior are the canopies of highly flammable understory species, and dead needles, twigs, and small branches suspended on understory vegetation or on the lower branches of unpruned crop trees. These suspended fuels are commonly referred to as ladder fuels because they provide a pathway for fire to carry from surface fuels into the crowns of shrubs and trees. Suspended fuel loads in pine plantations in the tropics tend to be heavy, creating hazardous burning conditions. Although living tree crowns become available fuels only under conditions favorable to the development of crown fires, their volume becomes highly important when timber-cutting operations convert them to logging residues.

\section{Debris Burning}

Depending upon arrangement and distribution, all but the larger size classes are generally available when broadcast burning logging debris. It is not generally necessary, nor desirable to consume all fuel on the site (see Sect. 12.2.2). If a burn objective is to consume larger fuels (over 5 or $6 \mathrm{~cm}$ in diameter), piling will probably be necessary. Mechanical piling in wet weather should be avoided. Keep the piles small, circular, and free of dirt. 


\subsubsection{Fuel Moisture}

The moisture content of forest fuel is the most important parameter affecting forest fire behavior. This quantity is in a constant state of flux as fuels respond to the ever-changing environmental factors of precipitation, humidity, and temperature. The size and shape of a dead fuel determines how fast it will take on or lose water in response to a change in its surrounding environment. Timelag is a measure of the speed of this response, the shorter the timelag the quicker the response. In the U.S. National Fire Danger Rating System (Deeming et al. 1977; Burgan 1988), fuels are classed by diameter or surface-to-volume ratio to fit 1 , 10,100 , or $1000 \mathrm{~h}$ timelag classes. Fuels less than about $6 \mathrm{~mm}(0.25 \mathrm{in})$ in diameter with a timelag of $1 \mathrm{~h}$ or less are called fine fuels or flash fuels and include grass, the uppermost layer of hardwood leaves and/or needles on the forest floor, and draped pine needles.

Before a fuel will ignite, the moisture in it has to be heated to the boiling point and evaporated, a process which takes considerable heat. Moreover, the resulting water vapor dilutes the oxygen and interferes with the gaseous phase of combustion. Thus when moisture content is high, fires are difficult to ignite, and burn poorly, if at all. With little moisture in the fuel, however, fires start easily, and tend to burn intensely and spread rapidly (Brown and Davis 1973).

\section{Underburning}

Fine-fuel moisture below 6 or $7 \%$ is a good indicator that conditions are too dry to prescribe burn; fires burn hotter, spotting is a problem, containment becomes more difficult, and overstory tree roots are very likely to be damaged. Although the usual objective of hazard reduction burns is to reduce fuel loading on the forest floor, this material should not be completely eliminated. The lower litter should always be checked before burning to make sure it feels damp; this will help ensure that some duff remains to protect the soil surface. A successful burn can be achieved even when the lower layer of the forest floor is soaking wet as long as the moisture content of the uppermost layer is below $30 \%$. As fine-fuel moisture approaches $35 \%$, however, prescribed fires tend to burn slowly and irregularly, often resulting in incomplete burns.

The rate of response of different fuel types can vary, and some types can reach different moisture contents under the same temperature/humidity conditions. For example, areas of cured standing grass can often be burned within hours of a drenching rain if good drying conditions exist. The drying process is slowed down inside a pine stand, depending upon factors such as stand density, height to the base of the overstory canopy, and the presence and stature of an understory. Workers have noted a fairly rapid decrease in fuel moisture during the morning and a much slower moisture recovery during the afternoon and evening, even with a rapid rise in humidity. McArthur (1971) reports that good burning conditions frequently occur in the late afternoon and evening when relative humidities are as high as 80 to $85 \%$. Because of these natural variations, 
on-the-ground knowledge of fuel moisture is essential. Burgan (1987a) compares three procedures for estimating the moisture content of fine dead fuels. Fuel moisture is so important that virtually all fire prediction schemes include some measure of it.

\section{Debris Burning}

After cutting, it takes at least several weeks for the severed tree tops to cure. If branch ends are left attached to larger pieces, the foliage acts as a wick and draws moisture from the larger-diameter fuels so that they dry faster than if cut into shorter lengths. Once the needles turn a greenish yellow the debris is ready to burn. Although heavy concentrations of fuel, such as harvested areas, will burn (once ignited) when fuel moistures are above 30\%, logging debris should be burned when dry: fuels will ignite more easily, burn more quickly and completely, require less mop-up and result in less of an impact on air quality. Teh-hour fuel moisture (fuels 0.6 to $2.5 \mathrm{~cm}$ in diameter) is a better indicator of burning conditions in logging debris than is fine-fuel moisture.

If logging slash is to be piled, allow this debris to cure for several weeks before piling because drying conditions are exceeding poor in the middle of a pile, especially if it is compacted or contains much dirt. Most of the smoke problems associated with burning are caused by inefficient combustion of damp soil-laden piles. These piles often smolder for weeks.

\subsubsection{Evaluating Fuel Inputs}

Numerous fuel classification schemes have been devised over the years to predict fire behavior and thus effects (e.g., Byrne 1980; de Ronde 1980; Fahnestock 1970). Such empirical models have many advantages, two major ones being their ease of construction and their ability to utilize accumulated experience. However, the importance of various fuel parameters can significantly change both spatially and temporally, and empirical models are rather inflexible. Models derived using a theoretical approach can accomodate such changes much easier (see Catchpole and de Mestre 1986 for an overview). A good example is the Australian MK III Prescribed Burning Guide developed for eucalypt fuels but also used in pine plantations. This empirical guide initially worked very well, but evolving site preparation, planting, and prescribed burning techniques have changed the fuels to the point where usefulness of the guide has been severely limited (Hunt and Crock 1987). Fuel classification using photographs is a widely used technique in the U.S. and photo series have been developed for most major fuel types (e.g., Anderson 1982). The technology is readily available (Maxwell and Ward 1980; Schmidt 1978).

In the United States, a system of user-friendly computer programs called BEHAVE has been developed to predict behavior of a fire. One of 13 stylized fuel models can be chosen or users can follow instructions to construct their own 
site-specific fuel models. Fuel data and prescribed weather conditions are combined with slope to produce fire spread and intensity outputs (Burgan and Rothermel 1984; Burgan 1987b). These programs will run on a hand-held calculator so they can be used in the field to make on-the-spot decisions as burning conditions change.

It is difficult to recommend what fuel appraisal method to use because, except for BEHAVE, most existing systems have been based on certain regional requirements. Users will have to evaluate these systems in light of their own requirements to determine whether they can use or modify an existing model, or will have to develop a new one.

Logging residue appraisal is a somewhat unique situation requiring different criteria because the majority of the fuels are severed tree parts. Methods to estimate these fuels have received much attention in the northwestern U.S. where large volumes are left on site after harvest of old-growth conifer forests. Examples include Brown (1974) and Puckett et al. (1979). Harvesting pine plantations results in much more complete utilization, so relatively little material is left on the site requiring treatment. Moreover, in the past this residue was usually concentrated into windrows or piles, which further reduced the need to develop models.

\subsection{Weather and Topographic Considerations}

Knowledge of weather is the key to successful prescribed burning! Given adequate fuel, it is past and current weather that determines if and how a fire will burn. Wind, relative humidity, temperature, and precipitation are the more important elements to consider. These factors all influence fuel moisture which, as mentioned previously, is the single most critical factor in determining fire behavior. If smoke management is a concern, airmass stability is also important. Good prescribed burning conditions may exist for only a short period of time (hours or days), so their impending arrival needs to be recognized as soon as possible to fully utilize them. In areas where extensive prescribed burning is done, good burning weather is usually the limiting factor, although aerial ignition techniques have helped tremendously in this area. If you contemplate using prescription fire, it is mandatory for you to become familiar with local weather patterns that are favorable for prescribed burning as well as local "watchout" situations. Before igniting a fire, always obtain the latest weather forecast for the day of the burn and the following night. When possible, get a 2-day weather outlook. Maximum daily fire danger generally occurs between 12.00 and $14.00 \mathrm{~h}$ in the tropics, but this is not necessarily when your meteorological agency takes its observations.

Weather observations should always be taken at a prescribed burn site prior to, during, and immediately after the fire. Such observations are important because they serve as a check on the weather forecast and keep the burning crew up to date on any local influences or changes. Precipitation amount in particular 


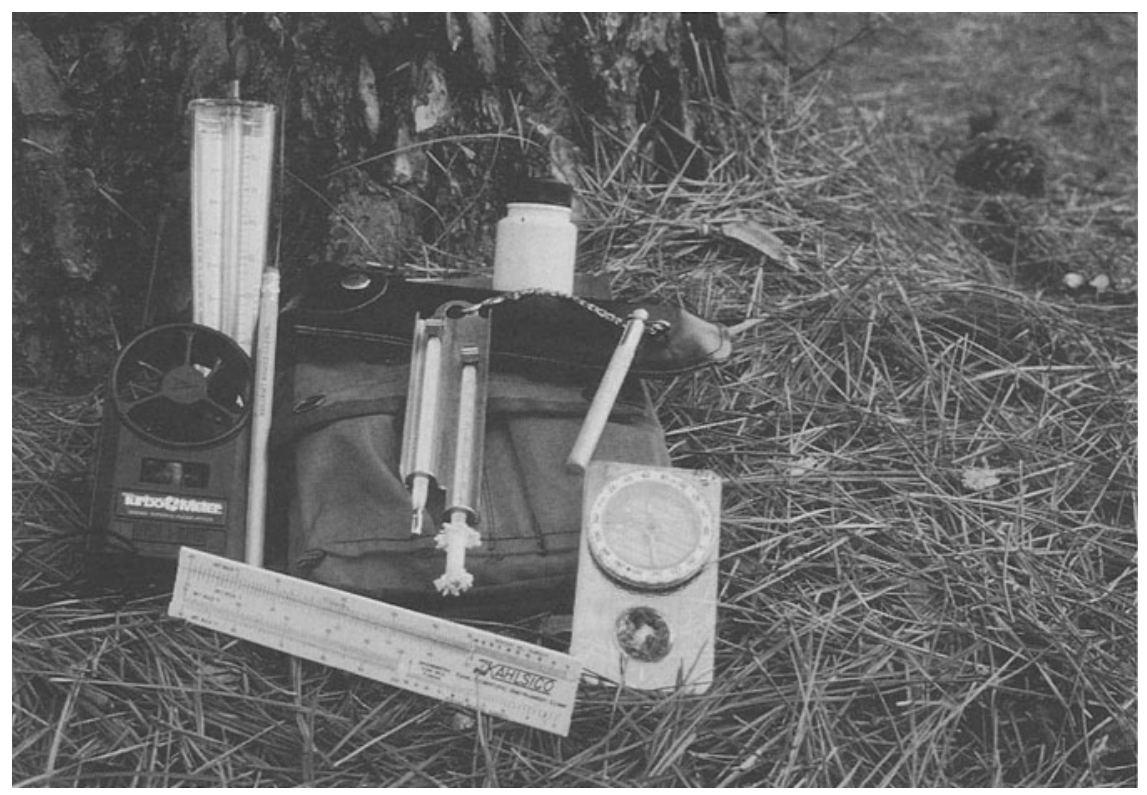

Fig. 3. A typical belt weather kit including additional wind meter

can vary widely between locations. Measurements taken in an open area, on a forest road, and in an adjacent stand are likely to be considerably different. Weather readings during a fire should be taken in a similar fuel type upwind of the burn to avoid heating and drying effects of the fire. Readings should be taken and recorded at 1 - to 2-h intervals during a fire and whenever a change in fire behavior is noticed. By taking periodic readings and observing cloud conditions, a competent observer can obtain a fairly complete picture of current and approaching weather. Inexpensive easy-to-use belt weather kits are available from forestry supply mail-order outlets in the U.S. and elsewhere (Fig. 3).

\subsubsection{Wind}

In level terrain, wind determines the direction of fire spread. On-site wind direction may be influenced by nearby topographic features and on-site windspeed will vary with stand density, understory stature, and height to the bottom of the forest canopy. Windspeed generally increases after daybreak, reaching a maximum in the early afternoon, and then decreases to a minimum after sunset. 


\section{Underburning}

The preferred prescribed burning windspeed range measured at eye level in a stand is 2 to $5 \mathrm{~km} \mathrm{~h}^{-1}$. These are the most desirable windspeed ranges for prescribed burning, but specific conditions may dictate other speeds. Windspeed readings in weather forecasts are, however, often taken about $6 \mathrm{~m}$ aboveground in the open and are the maximum expected, not the average for the day. The minimum $6 \mathrm{~m}$ windspeed for burning is about $10 \mathrm{~km} \mathrm{~h}^{-1}$. An often used maximum is about $32 \mathrm{~km} \mathrm{~h}^{-1}$, but higher windspeeds can probably be tolerated. This is because once the tree crowns have closed, eye-level winds in the interior of a stand rarely seem to exceed about $8 \mathrm{~km} \mathrm{~h}^{-1}$ regardless of the strength of the 6-m windspeed.

High windspeeds keep flames bent over and rapidly dissipate heat from a backing fire. The result is less crown scorch than from a fire backing into a low-speed wind. In-stand windspeeds should be in the low to middle range ( 2 to $3 \mathrm{~km} \mathrm{~h}^{-1}$ ) when heading fires are used. With high windspeeds, fires burning with the wind spread too rapidly and become too intense, dramatically increasing the probability of damage to the stand. On the other hand, enough wind should be present to keep the heat from rising directly up into tree crowns. Lulls in the wind allow flames to stand up straight, and heat to rise directly up into tree crowns.

Of equal importance to windspeed is the length of time the wind blows from one direction. Changes in wind direction mean changes in the rate of fire spread. Winds are characterized by continual deviations in speed and direction. Swings in wind direction of plus or minus 10 to $15^{\circ}$ are common and are of little consequence providing they do not persist. Changes greater than $45^{\circ}$, however, even if momentary, often result in hot spots (areas of crown scorch) when using a backing fire. Persistent steady winds are associated with certain weather patterns; become familiar with those in your area. For example, near large bodies of water, sea and land breezes are often utilized; but since they are diurnal phenomena, strict attention must be paid to arrival and departure times to avoid dangerous shifts in fire intensity.

\section{Debris Burning}

Winds are stronger in open areas than they are in the forest. Since there is no overstory to protect, some increase in fire intensity is acceptable. Moreover, wind is not needed to cool the heated combustion products. When broadcast burning, eye-level winds over 6 or $7 \mathrm{~km} \mathrm{~h}^{-1}$ can create containment problems if a heading fire is used. Always backfire the downwind side first! When piled or windrowed debris is burned, eye-level winds of 14 to $17 \mathrm{~km} \mathrm{~h}^{-1}$ can be tolerated by adjusting the firing pattern. Be aware of smoke-sensitive areas downwind and spotting potential.

With light variable winds, a convection column is often generated. Ignition patterns can be selected to encourage column formation in order to minimize fire control problems along the burn perimeter and to exhaust the smoke high 
into the atmosphere. where it quickly disperses with a minimum impact on ground-level air quality. Wind velocity (speed and direction) can change substantially with height and these upper (transport) winds determine offsite movement of the smoke. Some of these upper wind profiles have dangerous fire behavior characteristics associated with them (e.g., high spotting potential, or a sudden dramatic increase in fire intensity) and are called adverse profiles (Byram 1954). Thus knowledge of existing and forecast upper wind profiles is desirable before igniting a fire that is likely to generate a convection column. This information is, however, generally difficult to obtain. If near a commercial airport, a good source is the weather data used to brief pilots.

\subsubsection{Relative Humidity}

Relative humidity is an expression of the amount of moisture in the air compared to the total amount the air is capable of holding at that temperature and pressure. Each $11^{\circ} \mathrm{C}$ rise in temperature (which often occurs during the morning hours on a clear day) reduces the relative humidity by roughly half, and likewise, each $20^{\circ} \mathrm{C}$ drop in temperature (which often occurs in early evening) causes relative humidity to roughly double.

\section{Underburning}

Preferred relative humidity for prescribed burning varies from 30 to $50 \%$. In some locations relative humidities within this range rarely occur and burns have to be conducted under less than ideal conditions. When relative humidity falls below 30\%, prescribed burning becomes more dangerous. Fires are more intense under these conditions and spotting is much more likely; proceed only with additional precautions. When the relative humidity exceeds $60 \%$, a fire may leave unburned islands or may not burn hot enough to accomplish the desired objectives. However, when using aerial ignition in heavy fuels or under windy conditions when tall, partially cured grasses are abundant, even higher relative humidities may be desirable.

The moisture content of fine dead fuels (e.g., pine needles, cured grass) responds rapidly to changes in relative humidity but there is a timelag involved. Previous drying and wetting cycles and the amount of moisture in adjacent fuels and soil also influence response time. Therefore, relative humidity and fuel moisture should be assessed independently.

\section{Debris Burning}

Relative humidity (along with temperature) controls fuel moisture content up to about $32 \%$. Ignoring the movement of moisture from wet to drier layers of fuel or soil, liquid moisture such as rain or dew must contact a fuel for the moisture 
content to rise above $32 \%$. The extent of the rise depends upon both the duration and amount of precipitation.

Recently cut pine tops have a drying rate that is somewhat independent of relative humidity, but once this material initially dries to a moisture content below $32 \%$, it then behaves as other dead fuels and becomes more responsive to daily fluctuations in relative humidity. The response to changes in relative humidity is much more rapid in fine dead fuels suspended above the ground than it is in those that have become part of the litter layer. These suspended fuels are not in direct contact with the damp lower litter, and are more exposed to the sun and wind.

When burning piled debris, high humidities have little effect on fire behavior once large-diameter fuels have been ignited. Low humidities (below $30 \%$ ), however, will promote spotting and increase the likelihood that the fire will spread between piles.

\subsubsection{Temperature}

Temperature strongly affects moisture changes in forest fuels. High temperatures help dry fuels quickly. Fuels exposed to direct solar radiation become much warmer than the surrounding air. Moisture moves from warmer fuel to the air even if the relative humidity of the air is high. On the other hand, temperatures below freezing retard fire intensity because additional heat is required to convert ice to liquid water before it can be vaporized and driven off as steam. Consequently, it does not take much moisture under these conditions to produce a slow-moving fire that will leave unacceptably large areas unburned.

\section{Underburning}

The instantaneous lethal temperature of living plant tissue is about $62^{\circ} \mathrm{C}$. Cool air temperatures are thus recommended for hazard reduction burning because it is less likely that foliage and stem tissue will be heated to lethal temperature levels. When the objective is to control undesirable species, growing season burns with temperatures above $25^{\circ} \mathrm{C}$ are desirable. Lethal temperatures are more likely to be reached in understory stems and crowns with high ambient temperatures (see Sect. 12.8.1). Of, course, the overstory pines must be large enough to escape injury. Larger trees have thicker bark and their foliage is higher above the flames, which allows more room for the hot gases to cool before reaching the crowns.

\section{Debris Burning}

Cleared areas are often burned when ambient air temperatures are high. There is no overstory to protect and surface heating from direct sunlight usually 
increases the mixing height which helps disperse the smoke. It is particularly important to use an ignition pattern such as center firing when ambient air temperatures are high. This tactic creates strong convection in the center of the block. Then as the outside perimeter is ignited, the smoke from this ring fire is drawn away from the firelines to the central column thereby preventing heat damage to trees in adjacent stands and reducing the threat of an escape.

\subsubsection{Precipitation and Soil Moisture}

Rainfall has a pronounced affect on both fuel moisture and soil moisture. It is thus important to have a good estimate of the rain falling on an area to be burned for a few weeks prior to planned ignition. Rainfall amounts are fairly uniform with some large weather systems but they vary widely with others. Shower activity and amount is notoriously difficult to predict, even for nearby sites. The only reliable method to determine the a mount of precipitation that actually falls on a site is to place an inexpensive raingauge on the area.

\section{Underburning}

The importance of adequate soil moisture cannot be overemphasized. Damp soil protects tree roots and microorganisms. Underburning in pine plantations should cease during periods of prolonged drought and resume only after a soaking rain of at least $2 \mathrm{~cm}$. In older plantations that have been thinned or pruned and previously prescribed-burned, and which have a herbaceous groundcover and good air movement, it is sometimes possible to burn within 4 to $6 \mathrm{~h}$ after an early morning shower.

On soils with low infiltration and percolation rates, much rainfall is lost through runoff and duration is more important than amount. For example, on a typical clay soil in the southern U.S., $25 \mathrm{~mm}$ of rain occurring in $1 / 2 \mathrm{~h}$ will not produce as large a moisture gain as $13 \mathrm{~mm}$ falling over a 2 -h period.

\section{Debris Burning}

After a rain, fuels in cleared areas dry much faster than those under a tree canopy because of greater solar radiation and higher windspeeds. This differential drying can be used to advantage from a fire-control standpoint. Broadcast-burn the cleared area several days after a hard rain while fuels in the surrounding pine stands are still damp. Burning under these conditions assures good soil moisture. However, when burning harvested areas, soil damage is as much a function of fire intensity and duration as it is of soil moisture. Intense long-duration fires will bake the soil regardless of the moisture present. The biological, chemical, and physical properties of the soil are all likely to be altered (see Sect 12.8.4). Avoid these severe burns which alter the color structure of the mineral soil, 
particularly on clay soils and steep slopes. These undesirable fire effects are often produced when burning windrowed or piled debris, and are a major reason why piling and especially windrowing logging debris prior to burning is discouraged.

\subsubsection{Slope}

The slope of the land has an effect on rate of fire spread similar to that of wind. A $5^{\circ}$ slope will increase fire spread by $33 \%$ and a $10^{\circ}$ slope will double the forward rate of spread compared to that on level ground (McArthur 1971). When a fire burns upslope in the absence of wind, the flames are closer to the unburned fuels ahead of the fire than they would be on level ground. Since radiation decreases with the square of the distance, slope steepness has a significant affect on fuel preheating. By the same token, a fire will move downhill at a slower pace because of decreased preheating of fuels, but be on the lookout for rolling debris that can carry fire to the base of the slope where it will then spread rapidly back upslope at a much higher intensity. Because trees grow vertically and not perpendicular to a slope, the uphill sides of their crowns will be much closer to the ground and subject to increased fire damage.

As a slope is heated by the morning sun, an upslope convective flow develops. This breeze will increase to a maximum during the early afternoon and decrease to zero as the slope cools in the evening. As the slope continues to cool, a downslope wind will develop, reaching a reduced maximum after midnight. This breeze ends shortly after sun-up as the slope begins its daily heating cycle. If a fire is ignited at the base of a slope during the day, differential heating will be greatly increased and the fire will rapidly spread uphill. If this burned slope continues to smolder into the night, the smoke will drain downhill and concentrate in low areas.

\subsection{Fire Behavior Prediction}

Fire behavior is the result of the interaction between weather and fuel conditions, topography, firing technique, and ignition pattern. Measures of fire behavior are useful in comparing fires, in fire suppression planning, and in predicting fire effects. Uniform fire behavior descriptors are necessary for the accurate prediction of prescribed fire effects, but no single, easy-to-measure descriptor has emerged that can be used to assess adequately the full array of fire impacts on a site (Wade 1986). Rate of spread is of prime importance and is thus an integral part of many descriptors, but leaves much to be desired when used by itself. Several descriptors which have proven useful will be briefly discussed below, but each has limitations. Byram's Fireline Intensity is a good descriptor to use for correlating fire behavior with fire effects above the flame zone. Reaction intensity and residence time should both correlate well with fire effects resulting from flame contact. When belowground effects are of interest, either 
heat per unit area or depth of burn can be used. A number of alignment charts and nomographs have been developed that allow a person to switch from one fire behavior descriptor to another (e.g., Albini 1976; Andrews and Rothermel 1982).

\subsubsection{Descriptors}

\section{Fireline Intensity}

This descriptor is also called frontal fire intensity or Byram's Intensity. Byram (1959) defines this term as the heat energy released per unit length of fire front per unit time irrespective of the depth of the flame zone. It is the product of the low heat of combustion (heat yield), the weight of fuel consumed in the flame zone (available fuel), and the rate of fire spread (Byram 1959). The equation is:

$$
\begin{aligned}
& \mathrm{I}=\text { Hwr; where } \mathrm{I}=\text { fire intensity in } \mathrm{kW} \mathrm{m} \mathrm{m}^{-1}, \\
& \mathrm{H}=\text { heat yield in } \mathrm{kJ} \mathrm{kg}^{-1}, \\
& \mathrm{w}=\text { weight of available fuel in } \mathrm{kg} \mathrm{m}^{-2}, \\
& \mathrm{r}=\text { rate of spread in } \mathrm{m} \mathrm{s}^{-1} .
\end{aligned}
$$

The same output value can result from different values of input variables. The low heat of combustion approximates the heat yield and remains fairly constant so that for a given fireline intensity, a decrease in forward rate of spread implies an increase in the amount of fuel consumed. Slow rates of spread will thus concentrate more heat on the lower portion of a tree bole. Available fuel includes fuel consumed in the flame zone but not that consumed behind the flame zone (which can be considerable). In practice, however, consumption (which also includes that fuel consumed after the fire front passes) is often substituted for available fuel. Alexander (1982) presented an in-depth discussion of the attributes of this descriptor. Wade (1983) described fireline intensity levels and associated headfire behavior to help plan prescription burns in $P$. elliottii stands in the southern U.S.A. (Table 3).

\section{Reaction Intensity}

Originally called combustion rate by Byram (1959), this term is defined as the rate of heat release per unit area per unit time in the flame zone. It can be derived by dividing fireline intensity by flame zone depth. Again, the same output value can be produced by varying the values of the input variables.

\section{Residence Time}

Residence time is defined as the length of time it takes the flame zone to pass a given point. Numerically, it is the depth of the flame zone divided by rate of spread. As large fuels ignite and burn, residence time will increase, resulting in a stronger heat pulse to the site. 
Table 3. Fireline intensity guidelines for prescribed heading fires in P. elliottii stands

\begin{tabular}{ll}
\hline $\begin{array}{l}\text { Fire intensity } \\
\mathrm{kW} \mathrm{m} \mathrm{m}^{-1}\end{array}$ & Description of fire behavior \\
\hline$<70$ & $\begin{array}{l}\text { Intensity too low. Flame lengths less than } 0.3 \mathrm{~m} \text {. Very patchy burn. } \\
\text { Scorch not a problem. }\end{array}$ \\
\hline $71-250$ & $\begin{array}{l}\text { Optimum range. Flame heights } 0.3-0.9 \mathrm{~m} . \text { Scorch heights generally } \\
\text { below } 4.5 \mathrm{~m} \text {. Little chance of fires exceeding control lines. }\end{array}$ \\
\hline $251-425$ & $\begin{array}{l}\text { Too hot for use in immature stands. Flame heights } 0.9-1.1 \mathrm{~m} \text {. Scorch } \\
\text { heights } 4.5-9.0 \mathrm{~m} \text {. Downwind control line should be backfired before } \\
\text { setting headfire to prevent fire control difficulties. }\end{array}$ \\
\hline $426-700$ & $\begin{array}{l}\text { Upper fire intensity limits. Flame lengths generally below } 1.7 \mathrm{~m} . \\
\text { Scorch heights may be excessive even with steady winds. Always } \\
\text { backfire downwind side of plot first. Think twice about using a heading } \\
\text { fire. Have mechanized fire control equipment standing by. }\end{array}$ \\
\hline
\end{tabular}

\section{Heat per Unit Area}

The total amount of heat released per unit area during the time period combustion is taking place in that unit area is called the heat per unit area. It can be calculated directly by multiplying the low heat of combustion by the amount of fuel consumed. How this heat energy is distributed vertically within a unit area depends upon the dimensions of the flame envelope. Small flames will concentrate it near ground level, while longer flames will release some higher above the ground surface.

\section{Depth of Burn}

This parameter is simply a measure of the vertical depth that the forest floor was reduced during a fire. This descriptor has been expressed as the thickness of the layer removed, as a percentage of the total layer, and as the percentage of the burn upon which mineral soil was exposed. According to Alexander (1982), this depth depends mainly on the moisture gradient of the forest floor.

Even though two fires have the same descriptor value, the effects might be dramatically different. This anomaly can be caused for several reasons including: (1) the output values are only as good as the input values, (2) different combinations of intensity descriptor input variables can yield the same output value, (3) the variability inherent in most fires may make the mean value of a descriptor a poor indicator of fire effects, and (4) pre-fire and post-fire conditions such as plant vigor and the incidence of insect and disease attack may vary between sites. 


\subsubsection{Fire Behavior Models}

In the U.S.A. more than a decade of fire modeling has led to the creation of the BEHAVE computer program that can make use of 13 standard fuel models, revise them, or create new ones, and then combine the output with weather and topographic inputs to produce site-specific fire behavior predictions. (Andrews 1986; Burgan and Rothermel 1984). Rothermel's (1972) fire spread model is used for fire behavior calculations in BEHAVE. Recent work by Nelson and Adkins (1988) using dimensionless correlation has led to a much simpler model that expresses fire spread rate in terms of fuel consumption, ambient windspeed, and residence time. In Australia, a widely used method of predicting fire behavior was developed using fire danger meters to determine a fire danger index and a hazard rating from inputs of a drought index (McArthur 1966, 1967). Crane (1982) added pocket calculator programs to the system.

\subsubsection{Predicting Crown Scorch Height}

Crown scorch is often used as the primary indicator of burn success. Scorch becomes obvious soon after the burn, is easy to measure, and can result in reduced growth rates or even mortality. Scorch is a function of the amount of heat that reaches the canopy. It is dependent upon fire intensity, understory involvement which is reflected in flame length, the distance to the base of the crown, crown density, ambient temperature, and windspeed. In theory, scorch height should vary with the $2 / 3$ power of fireline intensity. Van Wagner (1973) validated these calculations based on field work in Canada. Interestingly, he found that including ambient temperature and eye-level windspeed did not significantly increase the reliability of his basic model:

$$
\begin{aligned}
h_{s}= & 0.1483(I)^{2 / 3} ; \text { where } h_{s} \text { is height in } \mathrm{m}, \\
& \text { and } \mathrm{I} \text { is fireline intensity in } \mathrm{kW} \mathrm{m}^{-1} \text {. }
\end{aligned}
$$

McArthur (1971) graphed the relationship between fireline intensity, scorch height, and flame height for P. elliottii and P. caribaea stands in Fiji. De Ronde developed a relationship based on a flame height:scorch height ratio of 1:6 with correction factors for windspeed and air temperature. The following tables can be used to arrive at these correction factors (Tables 4 and 5).

To arrive at predicted scorch height use the following procedure:

$($ Predicted scorch height $)=\{($ flame height $) \times 6\} \times($ wind correction factor $)$ $\times$ (temperature correction factor),

where both scorch height and flame height are in $\mathrm{m}$.

This height can now be compared with the distance to the bottom of the canopy to determine whether or not it is safe to burn. Increment loss usually does not occur until about $50 \%$ of the crown is damaged. Thus a good rule of thumb is to cancel a burn if scorch height is predicted to exceed $33 \%$ of the average crown height of the stand. Because $P$. caribaea can withstand 
Table 4. Scorch height correction factor for windspeed

\begin{tabular}{llllllll}
\hline \multirow{2}{*}{$\begin{array}{l}\text { Average flame } \\
\text { height }(\mathrm{m})\end{array}$} & \multicolumn{7}{c}{ Windspeed $\left(\mathrm{km} \mathrm{h}^{-1}\right)$ at ca. $6 \mathrm{~m}$ above the forest floor } \\
\cline { 2 - 8 } & 0 & 2.5 & 5.0 & 7.5 & 10 & 12.5 & 15 \\
\hline 0.25 & - & 0.83 & 0.67 & \multicolumn{2}{c}{ Unreliable data } & & \\
0.50 & - & 0.92 & 0.83 & 0.75 & 0.67 & 0.58 & 0.50 \\
0.75 & - & 0.94 & 0.89 & 0.78 & 0.67 & 0.58 & 0.50 \\
1.00 & - & 0.94 & 0.89 & 0.78 & 0.67 & 0.58 & 0.50 \\
1.50 & - & 0.94 & 0.89 & 0.81 & 0.72 & 0.61 & 0.50 \\
2.00 & - & 0.96 & 0.92 & 0.83 & 0.75 & 0.67 & 0.58 \\
2.50 & - & 0.98 & 0.97 & 0.92 & 0.87 & 0.81 & 0.77 \\
3.00 & - & 0.99 & 0.98 & 0.96 & 0.94 & 0.88 & 0.83 \\
\hline
\end{tabular}

Table 5. Scorch height correction factor for air temperature

\begin{tabular}{ll}
\hline Air temperature $\left({ }^{\circ} \mathrm{C}\right)$ & Scorch height correction factor \\
\hline $8-11$ & 0.6 \\
$12-15$ & 0.7 \\
$16-20$ & 0.8 \\
$21-24$ & 0.9 \\
$25-28$ & 1.0 \\
$29-32$ & 1.1 \\
$33-36$ & 1.2 \\
\hline
\end{tabular}

more scorch than other pines studied, McArthur (1971) suggested a scorch limit of $50 \%$ of the predominant stand height when prescribed burning under this species.

\subsection{Prescribed Burning Techniques}

Once the desired fire behavior is determined, the proper firing technique can be selected. The technique chosen must be closely correlated with burning objectives, fuels, weather, and topography to facilitate control and prevent damage to the resource. The proper technique to use can change as these factors change.

Fires either move with the wind (heading fire), against the wind (backing fire), at right angles to the wind (flanking fire), or in some combination of the above. The movement of any fire can be described in these terms. For example, a spot fire would exhibit all three types. Heading fire is the most intense because of its faster spread rate, wider flame zone, and longer flames. Backing fire is the least intense, having a slow spread rate regardless of windspeed. This type of fire has a narrow flame zone and short flames. If slight changes in fuels or weather are encountered, consider combining two or more firing techniques to achieve the desired result. A continuous line of fire always spreads faster and thus builds 
up intensity quicker than does a series of spot ignitions spaced along the same line. Fireline intensity abruptly increases when two fires burn together (called the convergence zone). The magnitude of this increase is greater when fires converge along a line rather than along a moving point. The line of scorch often seen paralleling a downwind control line delineates the zone where a heading and backing fire met.

The residence time of heading and backing prescribed fires is often about the same because the deeper flame zone of a heading fire compensates for its faster movement. Backing fires generally consume more forest floor fuels than do heading fires. The total heat applied to a site may be roughly equal for both heading and backing fires as long as additional fuel strata are not involved, but in a backing fire the released heat energy is concentrated closer to the ground.

Prescription fires are often ignited with driptorch fuel (consisting of 20 to $35 \%$ gasoline and 65 to $80 \%$ diesel or kerosene) dispensed manually from a driptorch (Fig. 4), or with flamethrowers which use gelled gasoline (made by mixing alumagel with gasoline). Common aerial ignition tools are the helitorch which also uses gelled gasoline and the Delayed Aerial Ignition Device (DAID) which is a round polystyrene capsule (hence the common name "ping-pong ball") containing potassium permanganate that is injected with ethylene glycol (antifreeze) to produce a thermo-chemical reaction. The two basic methods of igniting fires are as a solid line or as a series of point sources but many ignition tools cannot be used for both (at least from a practical standpoint). Ignition equipment must thus be compatible with ignition plans.

\subsubsection{Backing Fire}

A backing fire must be started along a downwind baseline such as a road or plowline and allowed to back into the wind. Variations in windspeed have little effect on the rate of spread of a fire burning against the wind. Some wind is necessary to give the fire direction but backing fires do not seem to spread much faster than about $1 \mathrm{~m} \mathrm{~min}^{-1}$ no matter what the windspeed. Backing fire is the easiest and safest type of prescribed fire to use provided windspeed and direction are steady. Once the fire backs away from the control line, escape is unlikely, resulting in less worry about damage to adjacent stands. Because crown scorch is minimized, this technique lends itself to use in heavy fuels. The initial fire in pine plantations should be a backfire except in rare instances such as young overgrazed stands where a continuous litter layer has not yet formed.

Major disadvantages are the slow progress of the fire and the increased potential for root damage if the lower litter is not moist enough. When a large area is to be burned, it often must be divided up into smaller blocks with interior plow lines (usually every 100 to $300 \mathrm{~m}$ ). These blocks must all be ignited at about the same time to complete the burn in a timely manner. Interior plow lines coupled with the extended burning period due to the slow rate of fire spread increase the costs of this technique. Once interior lines are constructed, changes in wind direction are difficult to accommodate. As fine-fuel moisture contents 

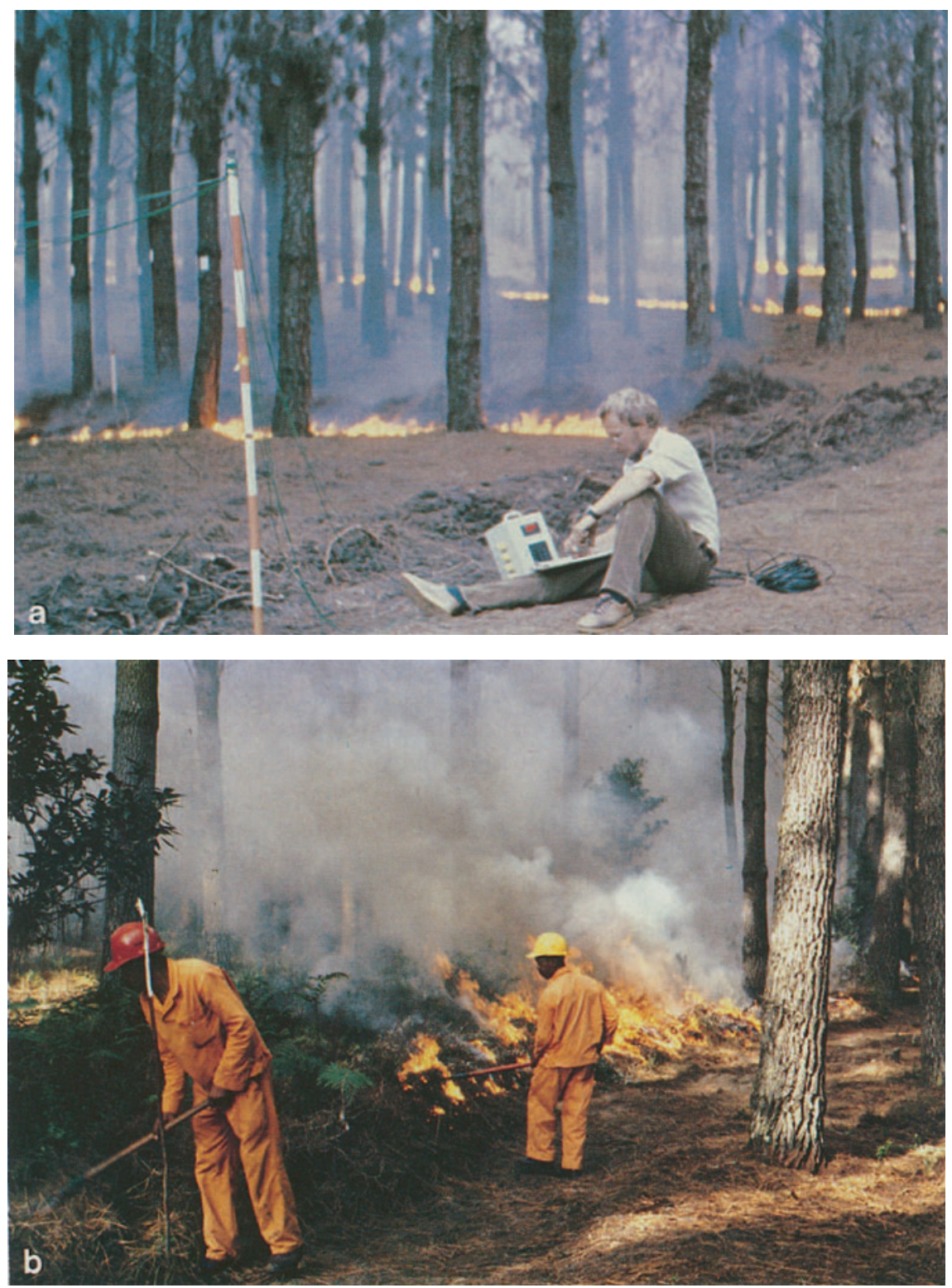

Fig. 4a,b. Conduction of a prescribed burn for research purposes in the State of Paraná, Brazil (a) and in management of pine plantations in the Cape Province, South Africa (b) 
approach $20 \%$ or when litter fuels are discontinuous, a backing fire will not carry well. Backing fires are line-source fires.

\subsubsection{Strip-Heading Fire}

In strip-head firing, a series of lines are set progressively upwind of a firebreak in such a manner that no individual line of fire can develop a high energy level before it reaches a firebreak or another line of fire. A backing fire should always be set first to secure the downwind base line and then the remainder of the area treated with strip-heading fires. Strips are often set 20 to $40 \mathrm{~m}$ apart. The distance between ignition lines is determined by the desired flame length. The spacing between lines should change throughout a burn to adjust for slight changes in topography, stand density, weather, or the type, amount, or distribution of fuel. Changes in wind direction of up to about $45^{\circ}$ can be accommodated during a fire by altering the angle of the strips. Strip-heading fires permit quick burnout and provide good smoke dispersion. A short distance between strips keeps an individual line of fire from gaining momentum but is time-consuming and uses a lot of torch fuel. Furthermore, higher intensities occur whenever lines of fire burn together, increasing the likelihood of crown scorch.

An effective method of reducing fire intensity is to use a series of spots or short 1- to 2-foot-long strips instead of a solid line of fire. An added advantage of these short strips or spots is that driptorches will not have to be filled as often. Prescribed burners often start with a backing fire, and after observing its behavior decide to try a few spots, and then a line of headfire if the spots behave as expected. They then increase the distance between successive strips until they reach the balance between speed and intensity that they are comfortable with. This technique is often used under high relative humidities (55 to 65\%) and high fine-fuel moistures (20 to 35\%), when backing fires will not accomplish the burn objectives. Heading fires are very sensitive to changes in windspeed. Only enough wind to give a heading fire direction ( 1 to $3 \mathrm{~km} \mathrm{~h}^{-1}$ in-stand) is needed because flame length and thus fireline intensity increase with wind speed. If interior plow lines are present and can be utilized so only a single line of heading fire is used in each small block, the number of zones of increased intensity where each heading and backing fire meet can be reduced or eliminated.

Allowing a heading fire to move across an entire block without stripping should only be done on areas with light fuel loadings. This generally restricts use of this technique to stands burned within the past 2 years. To reduce the potential of canopy scorch, heading fires are usually conducted in the winter when ambient temperatures are cooler.

\subsubsection{Point Source (Grid) Ignition}

Experienced prescribed burners often switch from one firing technique to another during a burn as conditions change. When properly executed, spot 
ignitions will produce a fire with an intensity about twice that of a line-backing fire, and roughly $66 \%$ that of a line-heading fire. Timing and spacing of the individual ignition spots are the keys to the successful application of this method. First a line fire is ignited across the downwind edge of the block and allowed to back into the block to increase the effective width of the control line. A line of spots is then ignited at some specified distance upwind of the backing fire and the process continued until the whole block has been ignited. The Australian Mk.III fire behavior tables state a grid pattern should be used such that individual fires will link-up in about $2 \mathrm{~h}$. In the USA, a pattern is usually selected such that link-up occurs within the first hour.

To minimize crown scorch, ignition-grid spacing is selected to allow the spots along a line to head into the rear of the spots along the downwind line before the flanks of the individual spots merge to form a continuous flame front. The merger of successive ignition lines thus takes place along a moving point rather than along a whole line at the same time. Merger along a moving point can be ensured by using a square grid. Close spacing between lines helps the individual spots to develop, but ensures that the head of one spot will burn into the rear of the downwind spot before the heading fire's potential flame length and intensity are reached. From a theoretical stand point, conditions should be such that the individual spots reach a quasi-steady state and can thus be allowed to run as long as burning conditions do not change. However, where the diurnal change in burning conditions is virtually continuous and of considerable magnitude grid spacing is, of necessity, much closer. McArthur(1971) states that the interaction between individual fires can begin at a distance of five times the flame height so that a convergence zone effect can occupy almost $50 \%$ of the burnt area. He believes this will trigger a mass fire effect almost instantaneously with even a 20 - to $40-\mathrm{m}$ grid pattern. This could certainly happen under severe burning conditions but a $40-$ by $40-\mathrm{m}$ grid is often used in the southern U.S. without undue worry.

Rectangular grids with wider spacing between lines than within a line should not be used because such a pattern may allow the spots along a line to merge into a line of heading fire before running into the rear of the downwind spots. Once the first few lines have been ignited and their fire behavior assessed, intensity can be regulated to some extent by changing the time between ignition points within a line, the distance between points, and the distance between lines. Thus the balancing act between spacing and timing should be continually adjusted as fire behavior reacts to both temporal and spatial changes in fuel and weather.

Intensity is decreased by widening the interval between ignition points along a line. If fireline intensity is still too high after doubling this interval while maintaining a $40 \mathrm{~m}$ distance between lines, firing should be halted. Allow the area to burn with a backing fire or plow it out. Although intensity of an individual spot is increased by widening the distance between lines, the average intensity of the burn as a whole is usually somewhat lower (because that portion of the area burned by heading fires decreases while that burned by flanking fires increases). Check to see that convergence zone flame lengths are within tolerable 
limits, and that other fire behavior para meters appear satisfactory. If everything is well within prescription, both the between- and within-line distances can be increased. This step will reduce ignition time and the amount of fuel used as well as decrease the number of convergence areas. The time needed to complete a burn can be reduced somewhat by offsetting successive ignition lines by one half of the within-line spacing. The heading fires from one line will then come up between the backing fires on the next line.

When using point source fires, much of the area will be burned by heading and flanking fires and very little by backing fires. Thus if conditions are ideal for line-backing fires, point source fires may get too intense. Preferred burning conditions include low ( 1 to $2 \mathrm{~km} \mathrm{~h}^{-1}$ ) in-stand eye-level windspeeds. Wind direction can be variable. Moisture content of the fine fuels should be above $15 \%$ and in many situations it should be above $25 \%$. Guidelines for using aerial ignition in pine plantations have been developed in Australia (Byrne and Just 1982) and preliminary recommendations made in the southern U.S. (Johansen 1987; Wade and Lunsford 1989).

\subsubsection{Edge Burning}

In those instances where it is not desired to prescribe-burn a plantation, fire is sometimes used to consume fine fuels around the periphery, or to treat the margins so as to create a buffer zone to stop or slow down an approaching wildfire. This practice is commonly called blacklining or edge burning, and can be very effective if done annually, although one must keep in mind that the woody understory will most likely be replaced by herbaceous fuels.

Although edge firing is not a firing technique in the true sense of the term, we include it here. Plantation edges generally burn with higher intensity than plantation interiors. The reasons for this are:

1. Edges are more exposed to the influences of sun and wind, leading to more rapid drying of fuels.

2. Increased sunlight at the edges stimulates the growth of understory species such as blady grass and bracken fern, which tends to cause fires to flare along these transitions zones.

3. Fire behavior at edges is influenced by wind. In plantations with a dense canopy the ratio of windspeed outside the forest to that inside is approximately 5 to 1 (Byrne 1980). Cooper (1965) and Albini and Baughman (1979) have developed some useful tables to predict windspeed inside stands. De Ronde has introduced these relationships in South Africa in a revised form.

Plantation edges are often burned soon after a rain before the plantation interior has dried sufficiently to carry fire. If nothing else is done, this process is called "blacklining", but if the interior is prescribed-burned at a later date, this is simply the first part of a two-step burn designed to minimize damage along the edge of the plantation. 


\subsubsection{Center and Circular (Ring) Firing}

This technique is useful on harvested areas where a hot fire is desired to reduce logging debris and kill any unwanted vegetation prior to planting. This procedure should never be used for underburning because of the likelihood of severe tree damage as the fire fronts converge. As with other burning techniques, the downwind control line is the first line to be ignited. Once the baseline is secured, the entire perimeter of the area is ignited so the flame fronts will all converge toward the center of the plot. One or more spot fires are often lighted in the center of the area and allowed to develop before the perimeter of the block is ignited. The convection generated by these interior fires creates indrafts that help pull the outer circle of fire toward the center, thereby reducing the threat of slop-overs and heat damage to adjacent stands.

Slash disposal burns using this technique can be conducted under a wide range of weather conditions because there is no overstory to worry about. Caution should be exercised, however, particularly when the atmosphere is unstable because this type of fire tends to develop a strong convection column. If the burning materials lifted aloft in this column are not completely consumed before they drop out downwind, a considerable spotting problem can develop. Although the probability of fire whirlwind development is low, they can be produced with this technique, especially where heavy fuel concentrations and uneven terrain exist.

\subsubsection{Pile and Windrow Burning}

The objective of piling logging debris before burning it is to prolong fire residence time thereby increasing the consumption of large materials. Windrowing should be avoided whenever possible, however, because of the high probability of site degradation. Large amounts of topsoil usually end up in the windrows, preventing an efficient burn. The use of heavy equipment during wet weather exacerbates this situation and can result in soil compaction. Full exposure of the soil to the sun bakes the top layer. Furthermore, the direct force of raindrops will clog soil pores and often results in erosion on slopes. The area beneath the windrows is lost to production because the debris is rarely consumed completely; and what remains makes planting difficult unless the material is repiled and reburned. Even when windrows contain breaks every 25 to $50 \mathrm{~m}$, they are a barrier to firefighting equipment and wildlife.

In many areas, the biggest deterrent to windrow burning is, however, its deleterious effect on air quality. Larger materials that often contain a lot of moisture are consumed, the windrow interior may not have dried, oxygen for good combustion is lacking in wide windrows, and large amounts of dirt are often mixed in. The result is a fire that continues to smolder for days or weeks. The smoke from smoldering combustion tends to stay near the ground, drifting and concentrating in low areas at night, resulting in potentially disastrous reductions in visibility. 
Broadcast burning is generally a much better alternative even if more thought has to be given to ignition patterns to prevent formation of a dangerous convection column. Industrial plantations contain little cull material so, even though the area may be covered with branches and tops after harvest, a broadcast burn will usually be sufficient to consume most fuels under $5 \mathrm{~cm}$ in diameter. In those instances where an unacceptable amount of large, scattered debris must be concentrated to ensure consumption, round "haystack" piles should be constructed (Johansen 1981). It generally costs a little more to pile than to windrow logging debris, but piles are preferable to windrows because access within the area is no problem, planting is easier, burning is safer, and smoke problems are significantly reduced since piles burn out much more quickly! Keep piles small and minimize the amount of dirt in them so surface water can pass through and the debris can quickly dry. Always machine-pile when the ground surface is dry; less soil compaction will take place, and considerably less soil will end up in the piles. Allow fresh logging slash to cure first and to dry after rain. Then shake the debris while piling to remove as much soil as possible. If material is piled while green or wet, the centers of the piles take an exceedingly long time to dry. Piles that contain little soil and are constructed to permit some air movement will result in a burn that consumes significantly more debris and is over with much quicker. Burning piles can easily be "bumped" to remove any dirt and pushed in to increase consumption.

Techniques used to burn piled debris are somewhat fixed because of the character and placement of the fuel. The upwind side of each pile should be ignited. Under light and variable winds, the whole pile perimeter can be ignited. Burn-out can be speeded up by using gelled gas which results in a quicker build up of fire intensity than with traditional driptorch fuel.

\subsection{Prescribed Burning Plans}

Planning a prescribed burn involves considerably more than just writing a burning plan. A successful prescribed fire is one that is executed safely and is confined to the planned area, burns with the desired intensity, accomplishes the prescribed treatment, and is compatible with resource management objectives. Such planning should be based on the following factors:

1. Physical and biological characteristics of the site to be treated.

2. Land and resource management objectives for the site to be treated.

3. Known relationships between preburn environmental factors, expected fire behavior, and probable fire effects.

4. The existing art and science of applying fire to a site.

5. Previous experience from similar treatments on similar sites (Fischer 1978).

6. Smoke impact from both an esthetic, and health and safety standpoint. 
The first step to a successful prescription is a stand-by-stand evaluation. Determine the needs of each stand and what actions should be taken to meet these needs. Alternatives to prescribed fire should be considered and a decision reached regarding the preferred treatment. Well in advance of the burning season, choose those stands to be burned. Overplan the number of acres to be burned during the coming season by 10 to $20 \%$ so substitutions can be made if necessary, and so additional areas can be burned if favorable weather continues. In many locations, the number of suitable burning days varies widely from year to year. Set priorities and specifically designate those burns which require exacting weather conditions. Considerations include heavy fuels, small trees, and potential smoke problems.

\subsubsection{The Written Plan}

The written burning plan should be prepared by a knowledgeable person prior to the burning season to allow time for interfunctional coordination and any necessary arrangements for manpower, equipment, financing, or other needs. Be ready to burn when the prescribed weather occurs. Some plans will be short and simple while others will be complex. In an area where broad variations in topography and type and amount of fuel exist, developing an effective burning prescription is difficult, if not impossible. Where practical, it is better to divide such areas into several burn units and prepare a separate burning plan for each. Treatment constraints should be included in, or attached to, the plan. Fischer (1978) named the following:

1. Environmental constraints (air quality, water quality, accelerated erosion).

2. Multiple use constraints (protection of other uses, resource management trade-offs).

3. Economic constraints (maximum cost per unit area).

4. Operational constraints (access, terrain, manpower).

5. Administrative constraints (policy, rules, etc.).

6. Legal constraints (fire laws, forest practice acts, etc.).

A prepared form with space for all needed information is best. The form will serve as a checklist to ensure that nothing has been overlooked. Numerous forms exist. A "simple" form that can be used on burns that are well within large landholdings that do not contain public roadways, and a form to use for post-harvest burns, both taken from Wade and Lunsford (1989), are presented (Fig. 5a,b). Some of the more important information that should be found in a plan is:

\section{Required Signatures}

Provide space for signature(s) of person who prepared the plan. This identifies the people who know most about the plan. 


\section{Simple Understory Prescribed Burning Unit Plan}

Landowner

Address

$\mathrm{S} \_\mathrm{T}$

Purpose of burn
Acres to Burn
Permit no.

Phone No.

Previous burn date

\section{(Draw map on back or attach)}

\section{Stand Description}

Overstory type \& Size

Understory type \& height

Height to bottom of crown

Dead fuels: description and amount

\section{Preburn Factors}

Manpower \& equipment needs

List smoke-sensitive areas \& locate on map

Special precautions

Estimated no. hours to complete

Adjacent landowners to notify

Passed smoke screening system

Weather Factors:

Surface winds (speed \& dir.)

Transport winds (speed \& dir.)

Minimum mixing height

Dispersion/stagnation index

Minimum relative humidity

Maximum temperature

Fine-fuel moisture (\%)

Days since rain

Amount

Fire Behavior:

Type fire

Best month to burn

Flame length

Rate of spread

Inches of litter to leave

Evalution:

Any escapes?

Objective met

Smoke problems

$\%$ of area with crown discoloration of

$$
5-25 \% \text { _ 26-50\% }
$$
$51-75 \%$

Acreage

Desired Range

Live crown consumption

$\%$ understory veg. consumed

Adverse publicity

Technique used OK

Remarks

Prescription made by

Title

Immediate

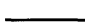

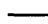

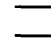

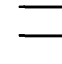

Desired Range

\section{-}

-




\section{Postharvest Prescribed Burning Unit Plan}

Prepared by Signature Date

State County District

Burning Unit No.

Landowner $\mathrm{S} \longrightarrow \mathrm{T} \_\mathrm{R} \_$Gross acres

Person responsible \& how to contact day \& night

A. Description of Area:

1, Natural stand or plantation

2. Clearcut

Harvest method (Draw map on back or attach)

3. Organic soil Stand age Harvest date

4. Unmerchantable trees felled Hardwood basal area

5. Unmerchantable trees felled Snags felled

6. Herbaceous fuels (light, medium, heavy)

7. Herbicide used

8. Drum chopped

9. Windrowed and/or piled

10. Pile or windrow dimensions: $\mathrm{Ht}$. Single or Double Pass Date piled

11. Windrow break interval

B. Preburn Factors and Desired Fire Intensity:

1. Areas to exclude:

2. Chains to plow (see map): Exterior

3. Chains to fire (see map): Exterior

4. Equipment needs

5. Crew size Interior Interior Total

Pine basal area removed Hardwoods utilized

Debris evenly distributed

6. Ignition procedure (see map):

7. No. of hours to complete

8. Special precautions: Brush (light, medium or heavy) Herbaceous fuels continuous Date applied Date Completed Permit no. Comp't Net acres

Notify:

10. Regulations that apply

11. Passed screening system? locate on map:

C. Weather Factors:

1. Surface wind (speed \& dir.)

2. Transport wind (speed \& dir.)

3. Mixing height

4. Dispersion Index (or comparable)

5. Relative humidity (\%)

6. Temperature (oF)

7. Fine-Fuel moisture (\%)

8. 10-hr. fuel moisture (\%)

9. Days since rain

10. Burning Index Amount

11. Best month to burn

12. Time of day to start Drought Index

D. Summary of Burn:

1. Type fire \& ignition

2. All piles, windrows \& logging decks ignited

3. $\%$ of area burned

4. Spotting frequency

E. Evaluation Immediately After Burn:
1. Any escapes: Number
2. Hours to burnout: Active flaming Adjacent to burn area?
3. \% understory veg. consumed
Smoldering Acres involved
4. $\%$ material $<3^{\prime \prime}$ dia. consumed Depth of litter remaining (in.)
5. Objectives met
6. Adverse publicity
7. Smoke problems
8. Remarks Distance

Did area between piles burn?

F. Future Evaluation (Date, signature and remarks)

Fig. 5b. 


\section{Purpose and Objective}

List the reason for prescribing the fire (e.g., reduce hazard). In addition give a specific quantifiable objective. State exactly what the fire is to do - what it should kill or consume, how much litter should be left, etc. Also concisely describe desired fire behavior including rate of spread, flame length, and fireline intensity. In case the prescribed weather conditions do not materialize, this description may provide some latitude so that firing techniques can be adjusted to accommodate the existing weather and still accomplish the objective(s). Such information will also be useful in determining success of the burn.

\section{Map of Burning Unit}

A detailed map of each burning unit is an important part of the burning plan. The map should show boundaries of the planned burn, adjacent landowners, topography, control lines (both existing and those to build), anticipated direction of smoke plume, smoke-sensitive areas, holding details, and other essential information. Show any areas that should be excluded or protected such as improvements.

\section{Equipment and Personnel}

List equipment and personnel needed on-site and on standby. Assign duties. Chain saws are a useful addition to the equipment list.

\section{Fire Prescription}

Include species involved, height to the lower crown, understory type and stature, presence and condition (cured or green) of herbaceous layer, and the continuity and amount of dead fuel by size class. List the desired range of pertinent weather factors including eye-level windspeed and direction, relative humidity, temperature, fine-fuel moisture content, precipitation, and drying days needed. These all determine the maximum intensity that can be tolerated and thus selection of a firing technique. State the type of fire, the desired rate of spread, flame length, fireline intensity, and estimated number of hours to complete the burn. Estimate the fuel amount by size-class to be consumed and/or the amount of litter to leave.

\section{Estimating the Available Number of Burning Days}

The correct season of the year when burning should be applied may differ from region to region. In those parts of the tropics and the adjoining regions where the climate is characterized by dry and rainy seasons, it is most suitable to burn during the transition period between the wet and the dry season. Local wind patterns, such as the "bergwind" in southern Africa, may considerably restrict the number of burning days. 
Time of Day

As a general rule, plan burning operations so the entire job can be completed within a standard workday. Prescribed fires usually are ignited between 10.00 and $14.00 \mathrm{~h}$. Some burners like to start early, as soon as the sun has evaporated any dew and then switch firing techniques as conditions change during the day. Others like to wait until the maximum burning conditions for a particular day have materialized around 13.00 or $14.00 \mathrm{~h}$ before igniting a burn. The decision depends somewhat upon your knowledge of local weather and the reliability of the forecast. Burning conditions are usually better during the day than at night because windspeed is higher and wind direction steadier. Relative humidity also often rises to unacceptable levels at night.

\section{Firing Plan}

The firing plan should consist of a narrative section and detailed map. The burning unit map is ideal for this purpose because it already contains much pertinent information. The following should be added: (1) firing technique, ignition method (e.g., driptorch), ignition pattern, and planned ignition time. (2) The planned distribution of manpower and equipment for setting, holding, patroling, and mopping up the fire and managing the smoke. (3) Location and number of reinforcements that can be quickly mobilized if the fire escapes. (4) Instructions for all supervisory personnel, including complete description or illustration of assignment, and forces at their disposal.

\section{Escaped-Fire Plan}

Identify potential fire escapes and specify actions to take should such occur. Designate who will be in charge of suppression action and what personnel and equipment will be available.

\section{Control and Mop-Up}

List the necessary safeguards to confine the fire to the planned area. Mop-up promptly and completely. Emphasize protection of adjacent lands.

\section{Evaluation}

A record of actual weather conditions, behavior of the fire, and its effects on the environment is essential. This information is used to determine the effectiveness of the burn and to set criteria for future burns. Just prior to igniting the burn, record windspeed and direction, relative humidity, temperature, fuel moisture, and dampness of soil and lower litter. Record applicable weather and fire behavior (e.g., flame length and rate of spread) parameters at 2- to 3-h intervals throughout the burn. After the burn, record the amount of crown scorch, consumption of understory, litter, and duff, and any other evidence of fire intensity such as unburned areas, exposed mineral soil, and cracks in bark or cupping on the lower bole due to bark consumption. Also include a short narrative on success of the burn. 


\subsubsection{Preparing for the Burn}

Good preparation is the key to successful burning. It is essential to maximize net benefits at acceptable cost. Preparation consists of all steps necessary to make the area ready for burning and of having all needed tools and equipment in good operating order and ready to go.

\section{Establishing Control Lines}

1. Construct lines in advance of burning, preferably after leaf fall to reduce the effect of fallen material on prepared lines.

2. Hold constructed lines to a minimum, keeping them shallow and on the contour as much as possible. Consider igniting from wetlines (a line of water, or water and chemical retardant sprayed along the ground to serve as a temporary control line from which to ignite or stop a low-intensity fire). Use access roads where feasible.

3. Use natural barriers such as streams whenever possible.

4. Keep control lines as straight as possible. Bend them around excluded areas, avoiding abrupt changes in direction.

5. Widen control lines at hazardous places.

After Lines Are Constructed

1. Remove any material above the line that could carry fire across the control line such as vines and overhanging brush.

2. Fell any snags near the line (inside and outside).

Burning-Unit Map

1. Locate all control lines on the map, noting any changes from the original plan.

2. Note on the map any danger spots along control lines having potential for fire escape.

\subsubsection{Executing the Burn}

There are few days of good prescribed burning weather during the year. When these days arrive, give top priority to burning. With adequate preparation, burning can begin without loss of opportunity. The person in charge should be an experienced prescribed burner with knowledge of the local situation. Radios for communication are useful. The person in charge must make sure the crew has the proper clothing and safety equipment and is in good physical shape. Have plenty of drinking water on hand.

Checklist

1. Make sure all equipment is in working order and safe to use.

2. Notify adjoining property owners and local fire control organizations before starting the fire. 
3. Carry burning plans and maps to the job.

4. Check all control lines, clean out needles and leaves, and reinforce as necessary.

5. Check duff and soil for dampness.

6. Post signs on public roads and be prepared to control traffic if visibility becomes dangerously impaired.

7. Check the weather before starting the burn and keep updated throughout the burn.

8. Instruct crew on procedures, including safety precautions and the proper operation of equipment and hand tools.

9. Inform crew of starting point and firing sequence. Give each member a map.

10. Have a means of instant communication with all crew members. Portable radios are very useful.

11. Test burn with a trial fire before firing; check the fire and smoke behavior to make sure the fire is burning as expected. If it is not, decide whether the observed behavior is acceptable. This is the time to cancel the burn if you are not comfortable with the observed behavior.

12. Burn so wind will carry smoke away from sensitive areas.

13. Be alert to changing conditions and be prepared to change burning techniques or put the fire out if an emergency arises.

14. Mop up and patrol perimeters constantly until there is no further danger of fire escape.

\subsubsection{Evaluating the Burn}

The purposes of a burn evaluation are to determine how well the stated objectives of the burn were met and to gain information to be used in planning future burns. An initial evaluation should be made within a day or two after the burn. A second evaluation should be made during or after the first post-fire growing season.

\section{Points to be considered}

1. Were objectives met?

2. Was burning plan adhered to? Were changes documented?

3. Were fuel conditions, weather conditions, and fire behavior parameters all within planned limits?

4. Was burning technique and ignition pattern correct?

5. Was fire confined to intended area?

6. Amount of overstory crown scorch and consumption?

7. Amount of litter remaining?

8. Effects on vegetation, soil, air, water, and wildlife?

9. How can similar burns be improved? 


\subsection{Fire Effects}

Fire effects depend upon the interaction of fire behavior and specific site characteristics such as species and age of vegetation, and soil type. Prescribed burning has direct and indirect effects on the environment. Effects can be shortor long-term and occur both on-and off site. The proper use of this tool requires knowledge of how fire affects vegetation, wildlife, soils water, and air. Burning technique, fire interval, and season of burn can be varied to alter fire effects. Robbins and Myers (1989) present an in-depth review of the seasonal effects of prescribed burning in Florida, U.S.A.

\subsubsection{Effects on Trees}

As the most valuable components of the plantation ecosystem are its trees, prediction of the occurrence and extent of fire injury should be a prerequisite to the intentional use of fire in these stands. Fire may kill part of a plant or the entire plant depending on how intensely the fire burns and how long a plant is exposed to these elevated temperatures. In addition, anatomical characteristics such as bark thickness and stem diameter influence a plant's susceptibility to fire. For example, small trees of a given species are easier to kill than large ones.

Very high temperatures are produced in the flames of burning forest fuels. Fortunately, the hot combustion gases are usually rapidly cooled in prescribed underburns unless the wind is calm. Wind is needed to dissipate the heat and slow its rise into the overstory canopy as well as to cool tree crowns heated by radiation. Ambient air and fuel temperatures at the time of burning are also important. When the air temperature is $9^{\circ} \mathrm{C}$, it takes twice as much heat to kill foliage at a given height above a fire as it does when the temperature is $34^{\circ} \mathrm{C}$. An extensive overview of the effects of fire on P. elliottii and P.taeda (which should also hold for the other species under discussion) is given by Wade and Johansen (1986).

\section{Cambium and Root Damage}

Pine bark has good insulating qualities and is what protects the aboveground cambium from injury. Bark thickness varies considerably within and between species. It thickens with age and especially with tree girth. Bark thicker than 12 $\mathrm{mm}$ will protect the stem cambium of most pines during prescribed fires (de Ronde 1982; Fahnestock and Hare 1964; Goldammer 1983; Kayll 1963). Susceptibility to cambial damage ranges from $P$. radiata and $P$. patula, the most susceptible, through $P$. taeda and $P$. pinaster, and finally to $P$. caribaea and $P$. elliottii, the most fire-resistant (de Ronde 1982; de Ronde et al. 1986; Langdon 1971; McArthur 1971; Speltz 1968; Van Loon and Love 1973).

Injuries to the cambium are not easy to detect from external signs. In 1966, Curtin stressed the need for a rapid nondestructive method to detect the 
presence of dead cambial tissue, but this challenge has yet to be met. Several methods of assessing cambial damage have been used (see Wade and Johansen 1986) but in practice, lifting of the bark (where damage is suspected) to detect discoloration is the simplest method (de Ronde et al. 1986; Fig. 6). Cambial damage is usually greatest on the lee side (in respect to fire passage) of a tree just above ground line (Fahnestock and Hare 1964). Except for $P$. radiata and $P$. patula, cambial damage is of little concern in low-intensity fires. Once $P$. elliottii and $P$. taeda reach a groundline diameter of roughly $5 \mathrm{~cm}$, they are pretty much immune to stem damage from prescribed fire (Johansen and Wade 1986).

Even though pine bark is a good insulator, cambial damage can occur from the extended smoldering of deep domelike accumulations of sloughed bark and needles around the root collar. This often results in death of the tree months later

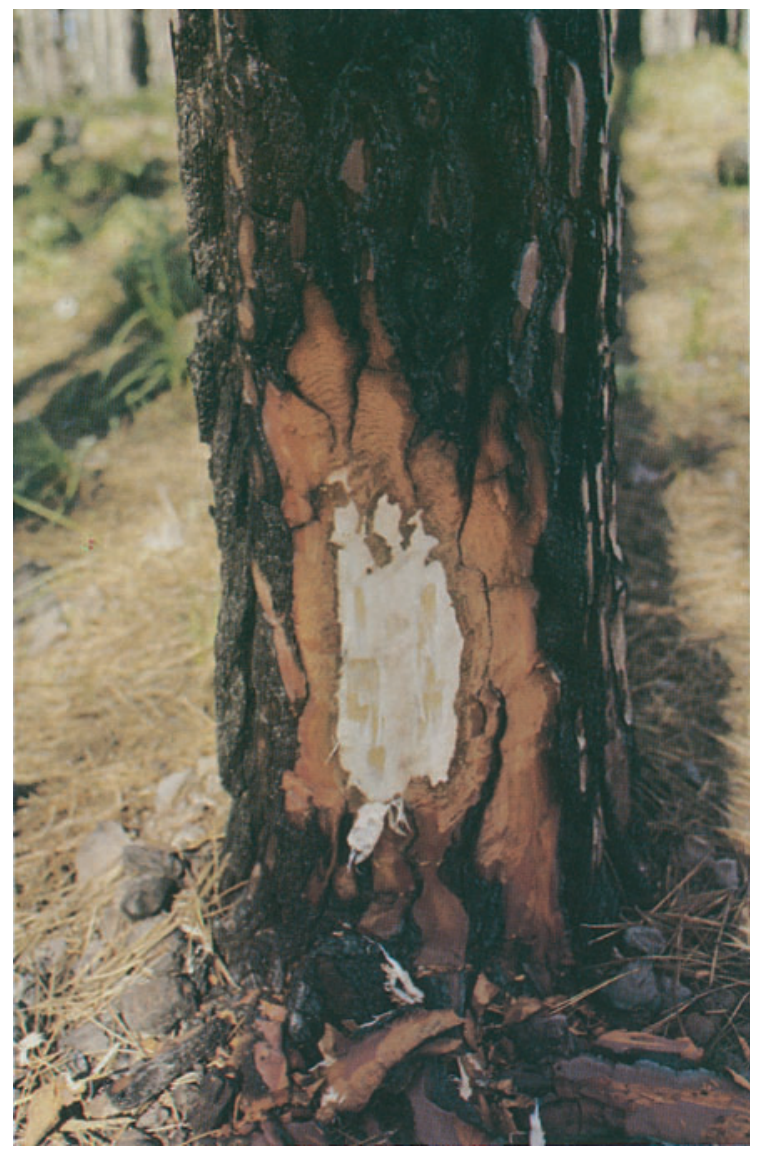

Fig. 6. Cambial damage in $P$. pinaster after a severe wildfire, Cape Province/South Africa. The brown areas on the exposed wood indicate areas of dead cambium 
Ferguson et al. (1960) noted this phenomenon in P. taeda. Whenever heat penetrates into the soil, feeder roots (which do not have a protective bark covering) are likely to be killed (see comments by Wade regarding $P$. elliottiivar. densa mortality in Wade and Johansen 1986). Root damage can be virtually eliminated during underburning by proceeding only when the duff is damp.

\section{Crown Damage}

Various researchers have observed that mortality is more closely related to crown damage than to cambial damage (Cooper and Altobellis 1969; Crow and Shilling 1980; de Ronde 1983; Jemison 1944). The best indicator of overstory damage (but not death) is percent foliage discoloration.

Pine foliage is quite vulnerable to temperatures above $55^{\circ} \mathrm{C}$. Nelson (1952) determined that the time needed to kill $P$. elliottii and $P$. taeda needles was almost instantaneous at $64^{\circ} \mathrm{C}$, averaged $30 \mathrm{~s}$ at $60^{\circ} \mathrm{C}$, and took about $6 \mathrm{~min}$ at $54^{\circ} \mathrm{C}$. Death of foliage on a few lower branches is of little consequence, but as crown scorch increases, the probability of reduced growth also increases. De Ronde has observed that the needles of $P$. radiata appear to be more easily heat-killed than those of several other species, perhaps because they are thinner in cross-section. P. caribaea, P. elliottii, P. pinaster, and P. taeda can all survive total needle scorch although some loss of height and/or diameter growth is likely. For example, Weise et al. (1989) reported results of a defoliation study in which 4-year-old P. elliottii and P. taeda pines were subjected to five defoliation levels $(100,95,66,33,0 \%)$ at four times (January, A pril, July, or October) at four different locations in the southeastern U.S. Six out of 30 P. elliottii defoliated $100 \%$ in October (fall), and all but one P. taeda defoliated $100 \%$ in October died. No other mortality occurred, but diameter and height growth of trees defoliated at the three most severe levels were significantly reduced (over $50 \%$ for some combinations). A similar study in $P$. radiata with similar results was reported by Rook and Whyte 1976).

Needle scorch, however, is not the principal cause of mortality in pines that do not have fully preformed buds. Damage to branch cambium and, especially buds, determines the survival potential of pines that routinely undergo several successive needle flushes during the growing season. The literature shows little mortality in these pine species until scorch approaches 100\%; but as consumption begins, dramatic increases in mortality take place (McCormick 1976; McCulley 1950; Tozzini and Soares 1987; Van Loon 1967; Wade 1985; Wade and Ward 1975). But how can an observer on the ground tell whether the buds or branch cambium have been thermally killed? One easy way is to use needle consumption as an analog of bud and cambium death. Temperatures over $200^{\circ} \mathrm{C}$ are required to ignite the foliage and these are high enough to kill surrounding meristematic tissue.

Post-fire damage surveys should be conducted within 2 to 3 weeks after a fire before the scorched needles fall. Dead foliage that is retained for much longer periods of time indicates that the branches themselves have also been killed. 


\section{Growth and Mortality Prediction}

A good rule of thumb is to assume that a tree's chances of survival are poor if more than $20 \%$ of the needles are actually consumed by flames even if the remaining foliage is not all scorched. Young vigorous trees are much more likely to survive severe crown damage than are older slower-growing or stressed individuals. Reports of survival after particularly extreme damage can be found (Goldammer 1983; Van Loon 1967; Wade and Ward 1975), but these instances should be considered fortuitous exceptions. Procedures for evaluating wildfire damage have been developed (e.g., Caulfield and Teeter 1988; de Ronde et al. 1986; McCulley 1950; Wade 1985).

The magnitude and duration of growth responses to various levels of fire-caused damage are critical needs that are only now emerging. Both negative and positive responses have been reported, but it is difficult to judge the true merit of many of these observations because fire behavior documentation is often not adequate and sometimes reconstructed at a later date; possible root damage has been almost universally ignored (see also Sect. 12.2.3); and diameter growth assessment techniques are sometimes flawed so that missing rings may be overlooked (see Wade and Johansen 1986). Many studies that tracked diameter and height response of severely damaged trees over time have recorded an inverse relationship between volume growth and damage (e.g., Bourgeois 1985; Weise et al. 1989). Even though increment loss can be substantial (e.g., Johansen and Wade 1987; Villarrubia and Chambers 1978), preburn growth rates are generally reestablished within a few years (e.g., McArthur 1971; Van Loon 1967; Weise et al. 1989). In fact, some studies have recorded an eventual increase in growth rate over the controls (e.g., Johansen 1975; Peet and McCormick 1971). Increased growth rates are a much more likely outcome when crown scorch is nonexistent or very light (e.g., Gruschow 1951, 1952; McCullley 1948, 1950). Several long-term studies that monitored tree growth over multiple burns found no significant differences between burned and unburned plots (e.g., Byrne 1977; Hunt and Simpson 1985; Sackett 1975), although two studies in $P$. palustris have documented retarded growth after several supposedly benign prescribed fires (Boyer 1987; Zahner 1989). De Ronde has unpublished findings that show no growth differences after a maximum of three fires over a 9-year period, and Wade has unpublished results that also show no growth differences after as many as 20 annual winter fires.

Of course, a well-conducted prescribed burn should not result in appreciable scorch, so the question of significant growth loss should be a moot point. However, recognizing that prescribed burns are sometimes hotter than planned, the following rules of thumb adapted from Wade and Lunsford (1989) are presented. They assume no needle consumption (Table 6). 
Table 6. Relationship between southern pine growth response and degree of crown scorch

\begin{tabular}{ll}
\hline $\begin{array}{l}\text { Percent } \\
\text { crown scorch }\end{array}$ & Damage \\
\hline 0 to 33 & $\begin{array}{l}\text { A slight increase in volume growth may occur the first post fire } \\
\text { year unless root damage occurs, in which case a minor growth } \\
\text { loss may occur. }\end{array}$ \\
$\begin{array}{l}\text { Volume growth loss usually less than } 40 \% \text { and confined to the } \\
\text { first post fire growing season. } \\
\text { Reduction may be as high as a full years growth spread over } 3 \\
\text { years. Some mortality may occur in } P \text {. pinaster and } P \text {. radiata. }\end{array}$ \\
\hline
\end{tabular}

\section{Secondary Damage}

Where trees have been subjected to severe fire-caused damage, bud elongation and some refoliation after the fire may give the impression that the trees are recovering. However, the new needle growth turns brown within a few months and the trees die. If root damage is not the cause, and post fire weather conditions have not resulted in additional stress, secondary pathogens are usually responsible. In industrial pine plantations in the Cape Province/South Africa, the main cause appears to be Rhizina undulata, which attacks the remaining live roots and is then followed by bark beetles (Ips) and cerambycid beetles which finish the job. This fungus is particularly common where fire has consumed all the humus (Baylis et al. 1986). Rhizina undulata has not caused problems to date after underburning, or after burning clearcut logging debris as long as the humus layer is not consumed, which suggests that high-intensity fires are necessary to create conditions favorable for the root rot (Baylis et al. 1986). Observations by De Ronde in the Cape forest regions support this hypothesis. In the Transvaal, Swaziland, and Natal, the abundance of Rhizina undulata fruiting bodies after slash burning forced forest managers to abandon this silvicultural practice because of the resulting high mortality in the next crop of pine seedlings (Donald 1979; Lundquist 1984). In many parts of the world, however, fire is used to dispose of logging slash and the associated insect populations that build-up in the freshly cut debris and stumps (e.g., Fellin 1980; Fox and Hill 1973; Hardison 1976; Smith et al. 1983).

There is little doubt that severely damaged pine stands attract and are more susceptible to insects and disease (e.g., Goldammer 1983; Martin and Mitchell 1980; Miller and Patterson 1927). However, some studies have also implicated low-intensity fires. For example, in Spain, De Ana Magan (1981) reported that prescribed fires in $P$. pinaster kill the natural control of Leptographium gallaeciae, thereby allowing this fungus to proliferate and attack the stand. On the other hand, Froelich et al. (1978) found that prescribed burning altered the forest floor environment to the detriment of Heterobasidon annosum, a particularly damaging fungus in pine plantations in the southern U.S. Investigations in the Philippines have shown that Ips interstitialis are attracted to freshly 
underburnt stands of $P$. kesiya by the monoterpenes released through the heating process in resinous fuels (Goldammer 1987). Schowalter (1983) described the adaptive abilities of insects to disturbances such as fire. The relationship between fire, insects and disease, and their host vegetation is a maze of complex, often subtle interactions that will require a holistic approach to unravel. An example of such an attempt is the work by Schowalter et al. (1981), who looked at Dendroctonus frontalis from the standpoint of the overall health of the southern pine ecosystem.

\subsubsection{Effects on Woody and Herbaceous Understory Vegetation}

The intensity and frequency of prescribed fire, the season during which fire is applied, the number of species present and their abundance, damage to plants and capacity of a species to regenerate after fire, all dictate the extent of fire impact and change in stand composition.

In the southern U.S., prescribed fire is routinely used to manipulate the herbaceous and woody understory for wildlife habitat improvement. Fire increases the amount and palatability of browse by stimulating sprout and sucker growth and keeps plant growth low - within reach of foraging animals. In Australia, Van Loon (1966) reported that higher strata shrubs such as Synoum, Cryptocarya, and Acacia can be drastically reduced by fire. De Ronde observed similar findings in South Africa with Laurophyllus capensis under mature P. elliottii overstory, while Soares had similar experiences with pine seedlings and small trees in Brazil. Wade et al. (1989) summarized the effects of 20 years of periodic burning on the composition and stature of the understory in a mixed pine/hardwood stand in the southern U.S.

The effects of a low-intensity prescribed burn on lower strata vegetation have such a broad range of possible outcomes that this discussion will be limited to a few examples. Van Loon (1966) recorded an increase in frequency of blady grass (e.g., Watsonia spp.) from 4.2 to $17.0 \%$ after a single burn. De Ronde observed similar frequency increases in grass communities such as Ehrharta spp. (63 to 84\%) in P. elliottii stands. In some cases, grass species are stimulated in clumps (Vlok and De Ronde 1989; Chippendal and Crook 1976). The improvements in Ehrharta frequency and density were always followed up by increased grazing by herbivores. The use of prescribed fire to manage herbaceous species' habitat in Africa has been reviewed by West (1965), and throughout the tropics by Campell (1960) and in various Tall Timbers Fire Ecology Conference Proceedings (see Fischer 1980).

Kellman and others (1987) have developed a scenario regarding underburning in P. caribaea stands in Belize that is based on both field data and computer simulations. Annual burning of this savanna results in a graminoid understory that is virtually all consumed in every fire. Less frequent burning cycles allow formation of a relatively nonflammable shrub layer. This shrub understory is capable of storing a much larger share of a site's nutrient capital than is the graminoid layer (except for phosphorus, which is unlikely to be lost 
from the site because it is rapidly immobilized by soil fixation). Low-intensity fires will topkill but not consume this shrub strata so that rather than being released all at once, the nutrients are mineralized over the ensuing months as the scorched leaves and fire-killed stems decompose. This gradual nutrient release significantly increases the probability that these minerals will again be captured by plants rather than leached from the site.

\subsubsection{Effects on Forest Floor Dynamics}

Fast-growing pine plantations tend to have a well-developed forest floor with deep, fairly distinct layers of undecomposed litter (AoooL), partly decomposed litter (AooF), and decomposed humus $(\mathrm{AoH})$. Litter decomposition rates are comparatively slow so that heavy accumulations of flammable fuel rapidly build up. Prescribed fire has a considerable effect on the physical, chemical, and biological environment of this forest floor. The amount of fuel removed from the forest floor by a fire depends upon the moisture content of the fuel and the residence time of the fire. The forest floor moisture regime is often characterized by a steep moisture gradient caused by fast drying of the upper litter and considerably slower drying of the $\mathrm{F}$ and $\mathrm{H}$ layers. In addition, the upper litter has a higher heat value and is less compacted than the lower strata (Hough 1969; Goldammer 1983). Due to the breakdown of all structures in partly decomposed needles, the water-holding capacity (maximum moisture content) increases considerably. Most workers have found the moisture retention capacity of total litter layers to range between 200 and 300\% (see Hough 1978) although Goldammer (1983) reported that 3-year-old $P$. taeda needles in the F/H layer may reach a moisture content of more than $600 \%$.

This distinct differentiation in the moisture regime of the forest floor facilitates removal of the most flammable and hazardous litter layer without affecting the lower layers. Consumption of the humus layers should be avoided in order to minimize the overall fire impact on the site and the stand. Exposing the underlying mineral soil predisposes the site to increased erosion and surface runoff.

\section{Needlefall and Crown Scorch Effects on Litter Loading}

The natural sloughing of old needles takes place throughout the year in pines although the great majority occurs during the fall months (Fig. 7). Many of the freshly shed needles lodge on lower branches and on the understory plants, where they remain until blown down by the wind. Variables determining the amount of needlefall include species, site productivity, basal area, and age of the stand. Lugo et al. (1980) estimate the production and storage of stemwood and organic matter in tropical plantations that shows the difference in performance between some of these pines. Data by Will (1959) presented in Bazilevic and Rodin (1966) give an annual foliage litter range of $2.9 \mathrm{t} \mathrm{ha}^{-1}$ to $10.4 \mathrm{t} \mathrm{ha}^{-1}$ 
Fig. 7. Average monthly distribution of needlefall (\% of annual needlefall) in 5- to 15-year old $P$. taeda plantations during 1981-82. Parana, Brazil. (Goldammer 1983)

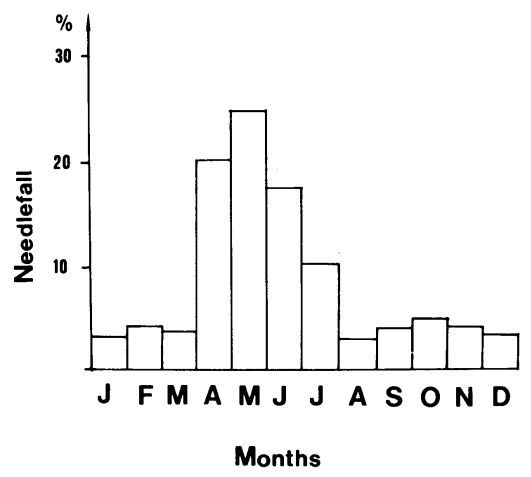

Fig. 8. Annual needlefall ( $\left.\mathrm{t} \mathrm{ha}^{-1}\right)$ by stand age in 5 to 22-year old $P$. taeda plantations during 1981-82. Parana, Brazil. (Goldammer 1983)

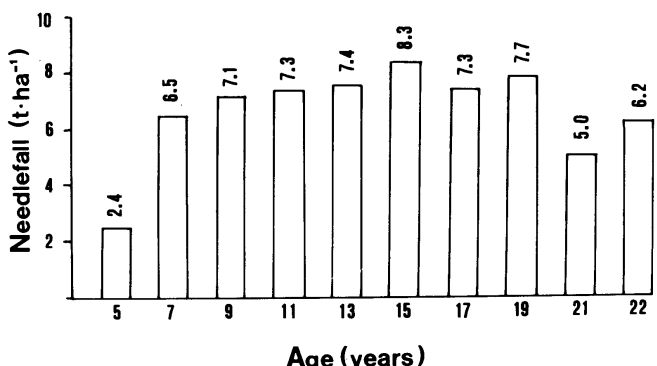

depending upon age for $P$. radiata plantations on the North Island of New Zealand. According to Bazilevic and Rodin (1966), in areas with a distinct dry period (such as dry savannas), the breakdown products are often completely neutralized by the bases due to maceration. The litter thus accumulates much faster than it decomposes. However, the colloidal complex that forms in these tropical savannas helps protect the humus during prescribed fires. Studies in $P$. elliottii and $P$. taeda plantations in southern Brazil showed that annual litterfall was higher there than in their natural range (Goldammer 1983). Figure 8 illustrates the annual needlefall in P. taeda plantations in Parana, Brazil in which the total dry weight increased from $2.5 \mathrm{t} \mathrm{ha}^{-1}$ in a 5-year-old stand to $8.3 \mathrm{t} / \mathrm{ha}$ in a 15-year-old stand and then slightly decreased at older ages.

Crown scorch will result in additional needlefall, the quantity dependent upon the amount of scorch. Sometimes the amount can be large enough to negate the reduction in hazard from the prescribed burn (Haigh 1980). In a prescribed burning experiment at Lottering, South Africa, in a 28-year-old $P$. elliottii stand, needlefall measured by De Ronde ranged from 6.5 tons/ha under unscorched trees (normal yearly needlefall) to 9.8 tons/ ha under trees with more than $75 \%$ of the crown scorched. The following illustration (Fig. 9) of the results also indicates that as the scorched needles fall to the ground during the first postburn month, they will partially off-set the litter reduction achieved by the fire. 


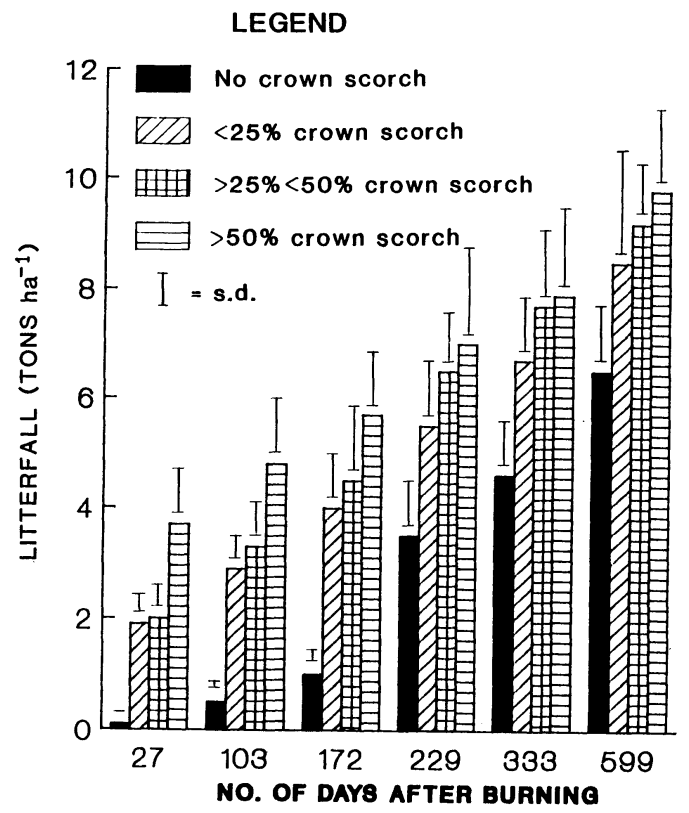

Fig. 9. Histogram of accumulated needlefall in a $P$. elliottii controlled burning trial by four levels of crown scorch. Lottering, South Africa

\section{Effects on Soil Fauna}

It is important to understand the effect of prescribed burns and wildfires on soil and litter invertebrates, since these animals have a direct and major role in litter decomposition and therefore nutrient cycling (Abbott et al. 1979; Reichle 1977). They also play an important part in maintaining soil structure (Abbott et al. 1979). Majer (1984) recorded significant long-term effects on some taxa but had little or no effect on other taxa. Abbott (1984) also reported little effect after fire in Jarrah forest of Australia.

All fires influence the biological and chemical processes taking place in the forest floor but intense postharvest fires can drastically alter the biological, physical and chemical characteristics of the upper soil (e.g., Neal et al. 1965). Common changes include increasing soil $\mathrm{pH}$ from 0.3 to 1.2 units, widening the $\mathrm{C}: \mathrm{N}$ ratio, and reducing soil-pore size, aeration, water-holding capacity and water infiltration rates (e.g., Debano 1981; Neal et al. 1965; Ralston and Hatchell 1971). These changes usually reduce microbial activities for varying periods after the burn (Ahlgren and Ahlgren 1960; Wright and Tarrant 1957). Reinoculation occurs from windblown spores or other debris and through invasion from subsurface layers. Because burning changes the soil's physical and chemical properties and eliminates many potential competitors, microbes adapted to the changed soil environment have an advantage in the recolonization process (Harvey et al. 1976). The typical increase in $\mathrm{pH}$ after fire favors bacterial population growth over fungal population growth. 
When moisture is sufficient, the microbial population quickly recovers, primarily from organisms adapted to the new soil environment. The reconstituted population may be greater and more active than the original one (Ahlgren and Ahlgren 1965), perhaps because of the large quantity of mineral nutrients released from the ash and because of other shifts in soil chemistry. For example, spores of the root pathogen Rhizina undulata germinate only after exposure to elevated temperatures (Gremmen 1971). It thereby gains access to soils that are rich in nutrients, that are likely to contain young and susceptible conifer roots, that harbor few competing organisms, and that have low concentrations of growth inhibitors (Watson and Ford 1972). Increases in other potential conifer root pathogens have also been recorded after burning (Tarrant 1956).

Temporary reductions in conifer-fungal mycorrhizal consociations have been found after intense post-harvest burns (Mikola et al. 1964; Tarrant 1956; Wright 1971, 1985; Wright and Tarrant 1957), but this is not a consideration when using low-intensity fires.

\subsubsection{Effects on Soil}

The impact of fire on soil depends upon such factors as the intensity, frequency, and residence time of the fire; type and moisture content of the soil; the moisture content and amount of protective forest floor; slope; and post-fire weather particularly precipitation. Wells et al. (1979) found that although both the productivity and stability of soils are adversely affected by excessive heat, low-intensity prescribed fires have little if any effect because they do not raise soil temperatures very much. They concluded further that low-intensity fires facilitate the cycling of some nutrients, may help control some plant pathogens and generally do not increase soil erosion. In contrast, intense fires can volatilize excessive amounts of nitrogen and other nutrients, destroy organic matter, change soil structure and may induce water repellency, thus increasing soil erosion and decreasing productivity potential (Byrne 1980). Good summaries of the effects of fire on soil are given by Brown and Davis (1973) and Wells et al. (1979).

\section{Physical Effects}

Prescribed burning generally has negligible effects on soil heating. Moisture in the lower duff and upper soil has to be evaporated before the temperature will increase much above $100^{\circ} \mathrm{C}$, which means that some humus remains to protect the soil after a properly conducted prescribed fire. In contrast, the complete consumption of the forest floor has a dramatic effect on soil surface temperatures (Clinnick 1984). Removal of litter is also likely to influence fine root growth by changing post-fire soil properties such as temperature, water, and compaction (Nambiar 1984). During a low-intensity prescribed fire in a 15 -year-old $P$. elliottii stand in southern Brazil in which the upper L-layer was burnt and the 
moist $\mathrm{F} / \mathrm{H}$-layer was left unburnt, the topsoil temperature was raised from 28 to $32^{\circ} \mathrm{C}$ for only a brief period (Goldammer 1983).

As might be expected, the net effect of burning is towards increased surface erosion (Tiedemann et al. 1979). If the forest floor is completely consumed, the underlying soil is exposed and thus vulnerable to raindrop impact. Soil aggregates are dispersed, pores become clogged, and macropore space, infiltration, and aeration are all decreased (Wells et al. 1979). Reduced evapotranspiration causes higher soil water contents that may lead to greater overland flow. Fire may reduce the "hydrologic depth" of a soil by causing formation of water-repellent layers. DeBano (1981) gives a state-of-the-art overview of water-repellent soils.

Virtually all the evidence in the southern U.S. suggests that none of the above deleterious effects will occur after well-planned low-intensity prescribed fires. The single possible exception is on fine-textured soils on steep terrain (Pritchett 1976). A study of the effects of fire during two different seasons in $P$. oocarpa on steep slopes in central Honduras concluded that the small increases in surface runoff and sediment loss were an acceptable alternative to letting the fuels build up, thereby exposing the site and overstory pines to the high risk of damaging wildfires (Hudson et al. 1983a).

\section{Chemical Effects}

The role of fire in nutrient cycling is still being unraveled in temperate forests. In the tropics and subtropics, Bazilevic and Rodin (1966) report that knowledge gaps are considerably larger. They go on to show that subtropical coniferous plantations are like their more temperate counterparts in that they take up and return much smaller amounts of chemical elements than do broadleaved forests.

Nutrient losses resulting from fires may occur by volatilization, by removal of particulate matter in smoke, by surface transportation in runoff, and by leaching through the soil (Harwood and Jackson 1975). Volatilization of elements requires high fire intensities so such losses are minimal in low-intensity prescribed fires. However, the consumption of plant materials mineralizes the nutrients stored in them irrespective of fire intensity. These released nutrients are available for immediate uptake by surviving rootstocks and new germinants, but are also subject to loss from surface runoff or leaching if not quickly captured by plants. Christensen (1987) points out that species inhabiting fire-dominated ecosystems in the southeastern U.S. a ppear to have developed traits that enable them to more efficiently retain and utilize fire-released nutrients. Precipitation affects the a mount of ash dissolved into the soil or carried away in overland flow. Hudson et al. (1983b), working in Honduras, determined that increased rates of sediment loss rather that increased losses in soil runoff were responsible for the increase in nutrient losses after prescribed burning.

Recovery after low-intensity fire is generally rapid even though natural mechanisms such as atmospheric deposition add nutrients to a site very slowly. Increases in $\mathrm{N}$-fixing organisms in many soils help offset any nitrogen loss (Metz 
et al. 1961; Wells 1971). Nitrogen-fixing plants such as legumes are usually promoted by low-intensity fires. Thus, the extent of $\mathrm{N}$ fixation and subsequent soil $\mathrm{N}$ transformations occurring after fire are critical factors in evaluating the long-term effects on site quality (Harvey et al. 1976). Hudson et al. (1983b) concluded that low-intensity underburns in $P$. oocarpa at least 3 years apart would reduce the rate of nutrient accumulation on the site rather than deplete the nutrient capital. Maggs (1988) took a more conservative approach; even though he found the nutrients in the forest floor had recovered 3 years after underburning a $P$. elliottii plantation in Australia, he cautioned that the repeated loss of nitrogen associated with periodic prescribed burning, when coupled with removal of logs at the end of a rotation, could lead to a depletion of total nitrogen over the long haul.

Close-interval prescribed burns may have the potential to eventually reduce the nutrient capital on some sites if a large portion of the nutrient capital is stored in the plant wastes being consumed. Humphreys and Craig (1981) summarized work done in Australian pine plantations regarding this potential. They reported that Jones and Richards (1977) found a slight but significant decrease in total nitrogen levels in soils that had been subjected to frequent low-intensity fires, but all other studies they refer to found no differences between plantations underburned and those in which fire had been excluded. McKee (1982) looked at soil fertility changes under pine stands in the southern U.S. that had been periodically underburned for 8 to 65 years. He found that these low-intensity fires had no deleterious effects on the soils and, in fact, consistently increased available phosphorus levels and prevented the immobilization of calcium in the forest floor, which could have led to a nutrient imbalance and accelerated soil weathering over time. In an exotic pine plantation in Australia, Hunt and Simpson (1985) even recorded a short-term increase of total phosphorus in both the surface and lower layers of the soil, which contrasted with a decrease in nitrogen. However, no consistent differences were recorded over a period of 9 years.

It is well established that available nitrogen in the soil is usually increased following burning. Davis (1959) concluded that the major reason for this was that fire somehow improves nitrification of the system. Maggs and Hewett (1985) found that the plots with the greatest nitrogen accumulation were the wettest and that this combination, together with the effects of burning, stimulated nitrogen fixation by anaerobic, nonsymbiotic microorganisms.

Davis (1959), Hough (1981), and Bara and Vega (1983) all recorded increased levels of K in the topsoil after prescribed fire, but Wells (1971) and McKee (1982) recorded no change. Similar increases have been recorded in the understory regrowth after fire, where potassium showed the most consistent response of all elements sampled (Harvis and Covington 1983). Because potassium leaches rapidly from ash, there may have been a mass ion movement into the soil, thus providing excess potassium for plant uptake (Grier 1975).

The ash from most plant materials is high in basic ions such as calcium, potassium, and magnesium. This tends to raise the $\mathrm{pH}$ of acid soils, especially sandy soils that are poorly buffered (Chandler et al. 1983). The literature also 
indicates that heat may have the same or an even greater effect on soil $\mathrm{pH}$ than oxides in the ashes (Wells et al. 1979). Davis (1959) suggests that the reduced acidity of the surface soil may be enough to stimulate nitrification and growth of subordinate vegetation but that most forest trees do not seem to be significantly affected by the changes in soil acidity brought about by fire.

The effect of fire on $\mathrm{pH}$ decreases rapidly with soil depth. Wells (1971) recorded an increase in $\mathrm{pH}$ form 3.5 to 4.0 in the $\mathrm{F}$ and $\mathrm{H}$ horizons after prescribed burning, and an increase in $\mathrm{pH}$ from 4.2 to 4.6 in the top $5 \mathrm{~cm}$ of the mineral soil. No significant changes were recorded by him in the $5-$ to $10-\mathrm{cm}$ layer of the mineral soil. McKee (1982) also recorded marginal $\mathrm{pH}$ increases after controled burning in coastal plain pine sites in the southern U.S.

The much more intense fires commonly associated with debris disposal after harvest are an entirely different situation. In the past, the use of fire to dispose of logging debris and prepare the site for reforestation was a very common practice. Rennie (1971) reported that prescribed fire was used on more than $90 \%$ of all sites in Australia prepared for conifer plantations, but the wisdom of this widespread practice has been questioned. Flinn (1978) showed retention of logging residue after clearcutting pine on infertile sandy soils enhanced early growth of the next crop. He believed that improved soil moisture conditions and the slow sustained release of nutrients over the ensuing years would result in better overall growth of the plantation. In contrast, Turvey and Cameron (1986) demonstrated that all three slash reduction treatments they tested resulted in better survival and growth than the "no treatment" alternative. Turvey and Cameron, do however, go on to warn that burning windrowed logging debris after several rotations could be detrimental to continued productivity because of changes in soil nutrient concentrations. Burning windrows releases the bound-up nutrients, making the soil under the windrows more fertile than the surrounding areas. Trees planted on these ashbeds grow faster than those on the degraded sites between windrows. According to Woods (1981), second-rotation productivity has declined by $37 \%$ on South Australian sites that have been subjected to very hot broadcast slash burns, and by 18 to $24 \%$ on windrowed sites, primarily due to the loss of nitrogen. In New Zealand, Phillips and Goh (1986) reported that both survival and growth of $P$. radiata seedlings were better on sites where logging debris was broadcast-burned than on those where it was unburned.

State-of-the-art pine plantation harvesting operations leave little logging debris on the site. For example, in the southern United States, fire is almost universally a part of reforestation even though the small amount of slash generated is only a minor hindrance to planting, and air quality concerns make planning and conducting these burns increasingly difficult. Fire alone or in combination with mechanical or chemical treatments temporarily eliminates competing vegetation until the pine seedlings become established. After a burn, equipment operators can more easily see the stumps of just-harvested trees as well as any other hazards. On more mesic sites where the ground surface is restructured into beds before planting, burning first, consumes much of the debris which would otherwise end up in the beds, resulting in a poor rooting 
medium and thus poor seedling survival. Broadcast burning mineralizes nutrients across the site, making them available for the next timber crop. With the notable exception of Rhizina undulata, prescribed fire helps sanitize a site, controling or reducing the potential for many insect and disease problems.

\subsection{Conclusions}

Fire produces change; whether these changes are deemed beneficial or detrimental depends upon specific burn objectives and overall resource management goals. The pines discussed in this chapter all have a close historic association with frequent fire. They each have evolutionary adaptations that help them predominate in fire-prone environments. In tropical and subtropical countries where prescribed fire is being used operationally or experimentally, the evidence leaves little doubt that its judicious use will result in a net benefit while its indiscriminate use will just as surely have deleterious effects. A total protection policy in industrial pine plantations invariably leads to a dangerous build-up of fuel on the forest floor that dramatically increases fire hazard. It will also result in an accumulation of nutrients in litter layers, and an undesirable habitat for herbaceous and woody plant communities necessary for biodiversity and thus ecosystem stability.

Prescribed fire is no panacea, however. There are trade-offs associated with every fire and in many situations fire may not be the best alternative. If it is the treatment of choice, good judgement in both planning and conducting the burn are mandatory. For instance, the potential of erosion on steep slopes has to be considered with care; but when fuel and weather conditions specified in a written plan of action materialize, this tool can be used to simultaneously accomplish several management and ecological needs. Because these needs are site-dependent, a plan of action that includes firing technique, ignition pattern, and expected fire behavior should be prepared for every burn. As an example, $P$. radiata has the lowest needlefall rate, the fastest litter decomposition rate, and is more susceptible to fire damage than the other species discussed, while $P$. caribaea has the opposite traits.

The evidence presented in this chapter strongly implies that well-planned and conducted prescribed burns should be one of the plantation managers' primary silvicultural tools to ensure sustained timber yields and properly maintained natural resources.

\section{References}

Abbott IC (1984) Changes in the abundance and activity of certain soil and litter fauna in the jarrah forest of Western Australia after a moderate intensity fire. Aust J Soil Res 22:463-469

Abbott IC, Parker CA, Sills ID (1979) Changes in the abundance of large soil animals and physical properties of soils following cultivation. Aust J Soil Res 17:343-352 (cited in Majer 1984) 
Ahlgren JT, Ahlgren CE (1960) Ecological effects of forest fires. Bot Rev 26:483-533

Albini FA (1976) Estimating wildfire behavior and effects. Gen Tech Rep INT-30. Ogden, UT: US Dept Agric, For Serv, Intermountain For Range Expt Stn, 92 pp

Albini FA, Baughman RG (1979) Estimating windspeeds for predicting wildland fire behavior. Res Pap INT-221. Ogden, UT: US Dept Agric, For Serv, Intermountain For Range Expt Stn, 12 pp Alexander ME (1982) Calculating and interpreting forest fire intensities. Can J Bot 60(4):349-357 Anderson HE (1982) Aids to determining fuel models for estimating fire behavior. Gen Tech Rep INT-122. Ogden, UT: US Dept Agric, For Serv, Intermountain For Range Expt Stn, 22 pp

Andrews PL (1986) Behave: fire behavior prediction and fuel modeling system - burn subsystem,

Part 1. Gen Tech Rep INT-194. Ogden, UT: US Dept Agric, For Serv, Intermountain For Range Expt Stn, $130 \mathrm{pp}$

Andrews PL, Rothermel RC (1982) Charts for interpreting wildland fire behavior characteristics. Gen Tech Rep INT-131. Ogden, UT: US Dept Agric, For Serv, Intermountain For Range Expt Stn, $21 \mathrm{pp}$

Bara S, Vega JA (1983) Effects of wildfires on forest soil in the northwest of Spain. In: Goldammer JG (ed) DFG-Symp Fire Ecology. Freiburger Waldschutz Abh 4, Freiburg, pp 181-195

Baylis NT, De Ronde C, James DB (1986) Observations of damage of a secondary nature following a wild fire at the Otterford State Forest. S Afr For J 137:36-37

Bazilevic NI, Rodin LE (1966) The biological cycle of nitrogen and ash elements in plant communities of the tropical and subtropical zones. For Abstr 27(3):357-368

Bourgeois DM (1985) Growth and mortality of dominant and co-dominant trees in prescribed burned pine plantations - first year results. Rep 6-85 Westvaco Tech Dept, Summerville, SC, $5 \mathrm{pp}$

Boyer WD (1987) Volume growth loss: a hidden cost of periodic prescribed burning in longleaf pine? So J Appl For 11(3): 154-157

Brown AA, Davis KP (1973) Forest Fire: Control and Use. 2nd edn. McGraw-Hill, New York, $686 \mathrm{pp}$

Brown JK (1974) Handbook for inventorying downed woody material. Gen Tech Rep INT-16. Ogden, UT: US Dept Agric, For Serv, Intermountain For Range Expt Stn, 24 pp

Burgan RE (1987a) A comparison of procedures to estimate fine dead fuel moisture for fire behavior predictions. S Afr For J 142:34-40

Burgan RE (1987b) Concepts and interpreted examples in advanced fuel modeling. Gen Tech Rep INT-238. Ogden, UT: US Dept Agric, For Serv, Intermountain For Range Expt Stn, 40 pp

Burgan RE (1988) 1988 revisions to the 1978 national fire-danger rating system. Res Pap SE-273. Asheville, NC: US Dept Agric, For Serv, Southeastern For Expt Stn, 39 pp

Burgan RE, Rothermel RC (1984) Behave: fire behavior prediction and fuel modeling system-fuel subsystem. Gen Tech Rep INT-167. Ogden, UT: US Dept Agric, For Serv, Intermountain For Range Expt Stn, $126 \mathrm{pp}$

Byram GM (1954) Atmospheric conditions related to blowup fires. Stn Pap 35. Asheville, NC: US Dept Agric, For Serv, Southeastern For Expt Stn 34 pp

Byram GM (1958) Some basic thermal processes controlling the effects of fire on living vegetation. Res Note 114. Asheville, NC: US Dept Agric, For Serv, Southeastern For Expt Stn, 2 pp

Byram GM (1959) Combustion of forest fuels. In: Davis KP(ed) Forest fire control and use. Chapter 3. McGraw-Hill, New York, pp 61-89

Byrne PJ (1977) Prescribed burning in Australia: the state of the art. Paper presented to 5th Meeting of Aust For Council Res Working Group No 6, Melbourne. (cited in Shea SR, Peet GB, Cheney NP 1981)

Byrne PJ (1980) Prescribed burning in Queensland exotic pine plantations. Proc 11th Commonw For Conf, Trinidad, $58 \mathrm{pp}$

Byrne PJ, Just TE (1982) Exotic pine plantation prescribed burning using a helicopter. Tech Pap 28 Dept For, Queensland, Australia

Campell RS (1960) Use of fire in grassland management. Paper delivered at Working Pary on Pasture and Fodder Development in Tropical America. FAO, Rome, $10 \mathrm{pp}$

Catchpole T, De Mestre N (1986) Physical models for a spreading line fire. Aust For 49(2): 102-111

Caulfield JP, Teeter LD (1988) Using break-even analysis for replanting decisions in damaged pine stands. So J Appl For 12:186-189 
Chandler C, Cheney P, Thomas P, Trabaud L, Williams D (1983) Fire in Forestry, vol 1. Forest Fire Behavior and Effects. Wiley, New York, $450 \mathrm{pp}$

Chippendal LKA, Crook AO (1976) Grasses of Southern Africa, vol I-III. Collins (Pty), Dublin House, Salisbury (Zimbabwe)

Christensen NL (1987) The biogeochemical consequences of fire and their effects on the vegetation of the Coastal Plain of the southeastern United States. In: Trabaud L (ed) The role of fire in ecological systems. SPB Academic Publishing, The Hague, Netherland, pp 1-21

Clinnick PF (1984) A summary-review of the effects of fire on the soil environment. Tech Rep Soil Cons Auth, View, Aust, 24 pp

Cooper RW (1965) Wind movement in pine stands. Georgia For Res Pap 33. Georgia For Res Counc, Macon, Georgia, $4 \mathrm{pp}$

Cooper RW, Altobellis AT (1969) Fire kill in young loblolly pine. Fire Cont Notes 30(4):14-15

Craighead FC (1977) Control burning will reduce forest fire hazards. Naples, FL: The Naples Star. Fri. May 20, 14A.

Crane WJB (1982) Computing grassland and forest fire behavior, relative humidity and drought index by pocket calculator. Aust For 45(2):89-97

Crow AB, Shilling CL (1980) Use of prescribed burning to enhance southern pine timber production. So J Appl For 4(1):15-18

Curtin RA (1966) The effects of fire on tree health and growth. In: The effects of fire on forest conditions. Tech Pap 13. For Comm NSW, Aust, pp 21-35

Davis KP (1959) Forest fire: control and use. McGraw-Hill, New York, 584 pp

Davis LS, Cooper RW (1963) How prescribed burning affects wildfire occurrence. J For 61(12):915-917

De Ana Magan FJF (1981) Controlled fires in forests induce attack of the fungus leptographium gallaeciae sp. Nov. on Pinus Pinaster. Forestal de Zonas Humedas, 37 pp. Dept For Zonas Humedas CRIDA, Pontevedra, Spain

Debano LF (1981) Water repellent soils: a state-of-the-art. Gen Tech Rep PSW-46. Berkeley, CA: US Dept Agric, For Serv, Pacific Southwest For Range Expt Stn, 21 pp

Deeming JE, Burgan RE, Cohen JD (1977) The national fire-danger rating system - 1978. Gen Tech Rep INT-39. Ogden, UT: US Dept Agric, For Serv, Intermountain For Range Expt Stn, $63 \mathrm{pp}$

de Ronde C (1980) Controlled burning under pines - a preliminary fuel classification system for plantations in the Cape. S Afr For J 113:84-86

de Ronde C (1982) The resistance of Pinus species to fire damage. S Afr For J 122:22-27

de Ronde C (1983) Controlled burning in pine stands in the Cape: the influence of crown scorch on tree growth and litterfall. S Afr For J 127:39-41

de Ronde C, Bohmer LH, Droomer AEC (1986) Evaluation of wildfire damage in pine stands. S Afr For J 138:45-50

Donald DGM (1979) Nursery and establishment techniques as factors in productivity of man-man forests in southern Africa. S Afr For J 109:19-25

Fahnestock GR (1970) Two keys for appraising forest fire fuels. Res Pap PNW-99. Portland, OR: US Dept Agric, For Serv, Pacific Northwest For Range Expt Stn, 26 pp

Fahnestock GR, Hare RC (1964) Heating of tree trunks in surface fires. J For 62(11):799-805

Fahnestock GR, Tarbes J, Yegres L (1987) The pines of Venezuela. J For 85(11):42-44

FAO (1982) Tropical forest resources. FAO For Pap 30, FAO, Rome, 106 pp

Fellin DG (1980) A review of some relationships of harvesting, residue management, and fire to forest insects and disease. In: Environmental consequences of timber harvesting in Rocky Mountain coniferous forests. Gen Tech Rep INT-90. Ogden, UT: US Dept Agric, For Serv, Intermountain For Range Expt Stn, pp 335-416

Ferguson ER, Gibbs CB, Thatcher RC (1960) "Cool” burns and pine mortality. Fire Cont Notes 21(1):27-29

Fischer WC (1978) Planning and evaluating prescribed fires. Gen Tech Rep INT-43. Ogden, UT: US Dept Agric, For Serv, Intermountain For Range Expt Stn, 19 pp

Fischer WC (1980) Index to the proceedings: Tall Timbers fire ecology conference, vol 1-15, 1962-1976. Gen Tech Rep INT-87. Ogden, UT: US Dept Agric, For Serv, Intermountain For Range Expt Stn, 140 pp 
Flinn DW (1978) Comparison of establishment methods for Pinus radiata on a former P. pinaster site. Aust For 41(3):167-176

Fox RC, Hill TM (1973) The relative attraction of burned and cutover pine areas to the pine seedling weevils Hylobius pales and Pachylobius picivorus. Ann Entomol Soc Am 66(1):52-54

Froelich RC, Hodges CS Jr, Sackett SS (1978) Prescribed burning reduces severity of Annosus root rot in the south. For Sci 24(1):93-100

Goldammer JG (1982) Controlled burning for stabilizing pine plantations. In: Proc Int Sem organized by the Timber Committee of the United Nations Economic Commission for Europe, Warsaw, Poland, 20-22 May 1981, Nijhoff/Junk, The Hague, pp 199-207

Goldammer JG (1983) Sicherung des südbrasilianischen Kiefernanbaues durch kontrolliertes Brennen. Hochschulsammlung Wirtschaftswiss, Forstwiss Bd 4, Hochschulverlag, Freiburg, $183 \mathrm{pp}$

Goldammer JG (1987) TCP Assistance to Forest Fire Management, The Philippines. For Fire Res. FAO, Rome, FO:TCP/PH1/66053(T), Work Pap 1, 38 pp

Gremmen J (1971) Rhizina undulata: a review of research in the Netherlands, Eur J For Pathol 1:1-6 (cited in Harvey et al. 1976)

Grier CC (1975) Wildfire effects of nutrient distribution and leaching in a coniferous ecosystem. Can J For Res 5:559-607

Gruschow GF (1951) Effect of winter burning on slash pine growth. Southern Lumberman, December 15 issue, $2 \mathrm{pp}$

Gruschow GF (1952) Effect of winter burning on growth of slash pine in the flatwoods. J For $50(7): 515-517$

Haigh H (1980) A preliminary report on controlled burning trials in pine plantations in Natal. S Afr For J 113:53-58

Hardison JR (1976) Fire and flame for plant disease control. Annu Rev Phytopathol 14:355-379

Harvey AE, Jurgensen MF, Larsen MJ (1976) Intensive fiber utilization and prescribed fire: Effects on the microbial ecology of forests. Gen Tech Rep INT-28. Ogden, UT:US Dept Agric, For Serv, Intermountain For Range Expt Stn, 46 pp

Harvis GR, Covington WE (1983) The effect of a prescribed fire on nutrient concentration and standing crop of understory vegetation in Ponderosa pine. Can J For Res 13(3):501-507

Harwood CE, Jackson WD (1975) Atmospheric losses of four plant nutrients during a forest fire. Aust For 38(2):92-99

Haywood JD (1986) Response of planted Pinus taeda L. to brush control in northern Louisiana. For Ecol Manage 15(2):129-134

Hedden RL (1978) The need for intensive forest management to reduce southern pine beetle activity in east Texas. So J Appl For 2(1):19-22

Helms JA (1979) Positive effects of prescribed burning on wildfire intensities. Fire Manage Notes 40(3):10-13

Hough WA (1969) Caloric value of some forest fuels of the southern United States. Res Pap SE-187. Asheville, NC:US Dept Agric, For Serv, Southeastern For Expt Stn, 12 pp

Hough WA (1978) Estimating available fuel weight consumed by prescribed fires in the south. Res Pap SE-187. Asheville, NC:US Dept Agric, For Serv, Southeastern For Expt Stn, 12 pp

Hough WA (1981) Impact of prescribed fire on understory and forest floor nutrients. Res Note SE-303. Asheville, NC:US Dept Agric, For Serv, Southeastern For Range Expt Stn, 4 pp

Hudson J, Kellman M, Sanmugadas K, Alvarado C (1983a) Prescribed burning of pinus oocarpa in Honduras I. Effects on surface runoff and sediment loss. For Ecol Manage 5(4):269-281

Hudson J, Kellman M, Sanmugadas K, Alvarado C (1983b) Prescribed burning of pinus oocarpa in Honduras II. Effects on nutrient cycling. For Ecol Manage 5(4):283-300

Humphreys FR, Craig FG (1981) Effects of fire on soil chemical, structural and hydrological properties. In: Gill AM, Groves RH, Noble IR (eds) Fire and the Australian Biota. Aust Acad Sci Canberra, ACT, pp 203-214

Hunt SM, Crock MJ (1987) Fire behavior modeling in exotic pine plantations: testing the Queensland Department of Forestry “prescribed burning guide mk III". Aust For Res 17(3):179-89

Hunt SM, Simpson JA (1985) Effects of low intensity prescribed fire on the growth and nutrition of slash pine plantations. Aust For Res 15(1):67-77 
Jemison GM (1944) The effect of basal wounding by forest fires on the diameter growth of some southern Appalachian hardwoods. Duke Univ Sch For Bull 9

Johansen RW (1975) Prescribed burning may enhance growth of young slash pine. J For 73(3): $148-149$

Johansen RW (1981) Windrows vs. small piles for forest debris disposal. Fire Manage Notes 42(2):7-9

Johansen RW (1987) Ignition patterns and prescribed fire behavior in southern pine stands. Georgia For Res Pap 72. Georgia For Comm Macon, Georgia, 6 pp

Johansen RW, Wade DD (1986) An insight into thinning young slash pine stands with fire. In: Proc 4th biennial southern silvicultural conference. 1986 November 4-6; Atlanta, GA. Gen Tech Rep SE-42. Asheville, NC:US Dept Agric, For Serv, Southeastern For Expt Stn, pp 103-106

Johansen RW, Wade DD (1987) Effects of crown scorch on survival and diameter growth of slash pine. So J Appl For 11(4): 180-184

Jones JM, Richards BN (1977) Changes in the microbiology of eucalypt forest soils following reafforestation with exotic pines. Aust For Res 7(4):229-240

Kayll AJ (1963) A technique for studying the fire tolerance of living tree trunks. Can Dept For Pub $1012,22 \mathrm{pp}$

Kellman M, Miyanishi K, Herbert P(1987) Nutrient sequestering by the understory strata of natural pinus caribaea stands subject to prescription burning. For Ecol Manage 21(1-2):57-73

Langdon OG (1971) Effects of prescribed burning on timber species in the southeastern coastal plain. In: Prescribed burning Symp Proc, 1971 Apr 14-16. Charleston, SC. Asheville, NC: US Dept Agric, For Serv, Southeastern For Exp Stn, pp 34-44

Lundquist JE (1984) The occurrence and distribution of Rhizina root rot in South Africa and Swaziland. S Afr For J 131:22-24

Luedge W (1971) Der Einfluss von Laubholzunterbau auf die Schädlingsdichte in den Kiefernbeständen der Schwetzinger Hardt. Allg Forst Jagdz 142:173-178

Lugo AE, Schimidt R, Brown S (1980) Preliminary estimates of storage and production of stemwood and organic matter in tropical plantations. In: Proc Int Symp IUFRO S1-07-09 Working Group at the Institute of Tropical Forestry, Rio Piedras, Puerto Rico, Sept 8-12, 1980, pp 8-16

Maggs J (1988) Organic matter and nutrients in the forest floor of a Pinus elliottii plantation and some effects of prescribed burning and superphosphate addition. For Ecol Manage 23: 105-119

Maggs J, Hewett RK (1985) Nitrogenase activity $\left(\mathrm{C}_{2} \mathrm{H}_{2}\right.$ reduction) in the forest floor on a Pinus elliottii plantation following superphosphate addition and prescribed burning. For Ecol Manage 14:91-101

Majer JD (1984) Short-term responses of soil and litter invertebrates to a cool autumn burn in jarrah (Eucalyptus marginata) forest in Western Australia. Pedobiologia 26(4):229-247

Maryland $\mathrm{G}$ (1988) The prospect of solving the $\mathrm{CO} 2$ problem through global reforestation. US Dept Energy DDE/NBB-082, 66p

Martin RE, Mitchell RG (1980) Possible, potential, probable and problem fire-insect interactions. In: Land-use allocation: process, people, politics, professionals, Proc 1980 Conv Soc Am For, pp 138-144

Maxwell WG, Ward FR (1980) Guidelines for developing or supplementing natural photo series. Res Note PNW-358. Portland OR: US Dept Agric, For Serv, Pacific Northwest For Range Expt Stn

McArthur AG (1966) Weather and grassland fire behavior. For Timb Bur Leafl 100, Canberra, ACT, $23 \mathrm{pp}$

McArthur AG (1967) Fire behavior in eucalypt forests. For Timb Bur Leafl 107, Canberra, ACT, $25 \mathrm{pp}$

McArthur AG (1971) Aspects of fire control in the P. caribaea and P. elliottii plantations of North Western Viti Levu Fiji Islands. Memeo Rep Canberra, ACT, 45 pp

McCormick J (1976) Recovery of maritime pine (Pinus pinaster) after severe crown scorch. For Dept West Aust Res Pap 20, 3 pp

McCulley RD (1948) Progress report on a study of the significant factors affecting fire injury and the effect of such injury on the mortality and growth of slash pine on the Osceola National Forest. Study No 0-113, Lake City, FL: US Dept Agric, For Serv, Southeastern For Expt Stn 
McCulley RD (1950) Management of natural slash pine stands in the flatwoods of south Georgia and north Florida. Circular 845. Washington, DC: US Dept Agric, For Serv, 57 pp

McDonald SE, Krugman SL (1986) Worldwide planting of southern pines. J For 84(6):21-24

McKee, WH Jr (1982) Changes in soil fertility following prescribed burning on coastal plain pine sites. Res Pap SE-234. Asheville, NC: US Dept Agric, For Serv, Southeastern For Expt Stn, 23 pp

Metz LJ, Lotti F, Klawitter RA (1961) Some effects on prescribed burning on coastal plain forest soil. Sta Pap 133. Asheville, NC: US Dept Agric, For Serv, Southeastern For Expt Stn, 10 pp

Mikola P, Laiho O, Erikainen J, Kuvaji K (1964) The effect of slash burning on the commencement of mycorrhizal association. Acta For Fenn 77(3), $12 \mathrm{pp}$

Miller JM, Patterson JE (1927) Preliminary studies on the relation of fire injury to bark-beetle attack in western yellow pine. J Agric Res 34:597-613

Munro N (1966) The fire ecology of caribbean pine in Nicaragua. In: Proc 5th Ann Tall Timbers Fire Ecol Conf, 1966 March 24-25, Tallahassee, FL, pp 67-83

Nambiar EKS (1984) Critical processes in forest nutrition and their importance for management. In: Landsberg JJ, Parsons W (eds) Research for forest management. CSIRO Div For Res Canberra, ACT, pp 52-72

Neal JL, Wright E, Bollen WB (1965) Burning Douglas-fir slash. Physical, chemical and microbial effects in soil. Unnumb Res Pap Corvallis, OR: Oregon State Univ For Res Lab, 32 pp

Nelson RM (1952) Observations on heat tolerance of southern pine needles. Sta Pap 14. Asheville, NC: US Dept Agric, For Serv, Southeastern For Expt Stn, $6 \mathrm{pp}$

Nelson RM Jr, Adkins CW (1988) A dimensionless correlation for the spread of wind-driven fires. Can J For Res 18:391-397

Peet GB, McCormick J (1971) Short-term responses from controlled burning and intense fires in the forests of western Australia. Bulletin 79. For Dept, Perth West Aust, 24 pp

Phillips MJ, Goh KM (1986) Growth response of pinus radiata to fertilizer and herbicide treatment in a clearfelled logged and a clearfelled, logged and burned northofagus forest. NZJ For Sci 16(1):19-29

Pritchett WL (1976) Considerations in use of fire by prescription for managing soil and water. In: Proc fire by prescription Symp, 1976 October 13-15, Atlanta, GA, Washington, DC: US Dept Agric, For Serv, pp 33-35

Puckett JV, Johnston CM, Albini FA et al. (1979) Users' guide to debris prediction and hazard appraisal. Unnumb Pub Missoula, MT: US Dept Agric, For Serv, Northern Forest Fire Lab, Intermountain For Range Expt Stn Rev 1979, 37 pp

Ralston CW, Hatchell GE (1971) Effects of prescribed burning on physical properties of soil. In: Proc Prescribed burning Symp, 1971 Apr 14-16; Charleston SC. Asheville, NC: US Dept Agric, For Serv, Southeastern For Expt Stn, pp 68-84

Reichle DE (1977) The role of soil invertebrates in nutrient cycling. In: Lohm V, Persson T (eds) Soil organisms as components of ecosystems. Stockholm: Swed Nat Sci Res Counc (cited in Majer 1984), pp 145-156

Rennie PJ (1971) The role of mechanization in forest site preparation. Paper presented at XV IUFRO Congress, Sec 32, Gainesville, FL, 38 pp

Robbins LE, Myers RL (1989) Seasonal effects of prescribed burning in Florida: a review. Tallahassee, FL: The Nature Conservancy, Fire Manage Res Prog, 86 pp

Rook DA, Whyte AGD (1976) Partial defoliation and growth of 5-year-old radiata pine NZJ For Sci 6(1):40-56

Rothermel RC (1972) A mathematical model for predicting fire spread in wildland fuels. Res Pap INT-115. Ogden, UT: US Dept Agric, For Serv, Intermountain For Range Expt Stn, 40 pp

Sackett SS (1975) Scheduling prescribed burns for hazard reduction in the southeast. J For 73(3): 143-147

Schmidt RG (1978) An approach to hazard classification. Fire Manage Notes 39(4):9-11

Schowalter TD (1983) Chapter 13: Adaptations of insects to disturbance. In: Pickett STA, White PS (eds) Natural disturbance: an evolutionary perspective. Academic Press, London

Schowalter TD, Coulson RN, Crossley DA Jr (1981) Role of southern pine beetle and fire in maintenance of structure and function of the southeastern coniferous forest. Environ Entomol $10(6): 821-825$

Schutz CJ (1987) Litter under patula. In: Res Rev, S Afr For Res Inst, pp 35-36 
Shea SR, Peet GB, Cheney NP (1981) The role of fire in forest management. In: Gill AM, Groves RH, Noble IR (eds) Fire and the Australian Biota. Aust Acad Sci, Canberra, ACT, pp 443-470

Smith D, Mrowka R, Maupin J (1983) Underburning to reduce fire hazard and control Ips beetles in green thinning slash. Fire Manage Notes 44(2):5-6

Speltz GE (1968) Resistencia ao fogo de diversas especies florestais registrados na Fazenda Monte Algre - Parana Anais Congr. Flor Brazil, Curitiba, 350 pp

Stewart RE, Gross LL, Honkala BH (1984) Effects of competing vegetation on forest trees: a bibliography with abstracts. Gen Tech Rep WO-43. Washington DC: US Dept Agric, For Serv

Tarrant RF (1956) Effects of slash burning on some soils of the Douglas-fir region. Soil Sci Soc Am Proc 20:408-411

Tiedemann AR, Conrad CE, Dieterich JH et al. (1979) Effects of fire on water. A state-of knowledge review. Proceedings of national fire effects workshop, 1978 Apr 10-14; Denver, CO. Gen Tech Rep WO-10. Washington, DC: US Dept Agric, For Serv, 28 pp

Tozzini DA, Soares RV (1987) Relacoes entre compartamento do fogo e danos causados a um povomento de Pinus taeda. Floresta 17(1,2):9-13

Turvey ND, Cameron JN (1986) Site preparation for a second rotation of radiata pine: soil and foliage chemistry, and effect on tree growth. Aust For Res 16(1):9-19

Van Loon AP (1966) The effects of fire on understory vegetation. In: The effects of fire on forest conditions. Tech Pap 13, For Comm NSW, Australia, pp 44-52

Van Loon AP (1967) Some effects of a wild fire on a southern pine plantation. Res Note 21, For Comm NSW, Australia, $38 \mathrm{pp}$

Van Loon AP, Love LA (1973) A prescribed burning experiment in young slash pine. Res Note 25, For Comm NSW, Australia, 53 pp

Van Wagner CE (1973) Height of crown scorch in forest fires. Can J For Res 3(3):373-378

Vega JA, Bara S, Del Carmen G (1983) Prescribed burning in pine stands for fire prevention in the N.W. of Spain: Some results and effects. In: Goldammer JG (ed) DFG- Symp fire ecology. Freiburger Waldschultz Abh 4, Freiburg, pp 49-74

Villarrubia CR, Chambers JL (1978) Fire: its effects on growth and survival of loblolly pine, Pinus taeda L. Louisiana Acad Sci 41:85-93

Vlok JHJ, De Ronde C (1989) The effect of low-intensity fires on forest floor vegetation in mature Pinus elliottii plantations in the Tsitsikamma. S Afr J Bot 55(1):11-16

Wade DD (1983) Fire management in the slash pine ecosystem. In: The managed slash pine ecosystem Symp Proc, 1981 June 9-11; Gainesville, FL: Univ Florida, Sch Nat Resour, pp 203-227, 290-294

Wade DD (1985) Survival in young loblolly pine plantations following wildfire. In: Proc 8th Nat Conf on fire and forest meteorology, 1985 April 29-May 2; Detroit, MI. Washington DC: Soc Am For, pp 52-57

Wade DD (1986) Linking fire behavior to its effects on living plant tissue In: Proc 1986 Soc Am For Nat Convention, 1986 October 5-8; Birmingham, AL. Washington, DC: Soc Am For, pp 112-116

Wade DD, Johansen RW (1986) Effects of fire on southern pine: observations and recommendations. Gen Tech Rep SE-41. Asheville, NC: US Dept Agric, For Serv, Southeastern For Expt Stn, 14 pp

Wade DD, Lewis CL (1987) Managing southern grazing ecosystems with fire. Rangelands 9(3):115-119

Wade DD, Lunsford JD (1989) A guide for prescribed fire in southern forests. Tech Pub R8-TP 11. Atlanta, GA, US Dept Agric, For Serv, So Region, $56 \mathrm{pp}$

Wade DD, Ward DE (1975) Management Decisions in severely damaged stands. J For 73(9):573-577

Wade DD, Weise DR, Shell R (1989) Some effects of periodic winter fire on plant communities on the Georgia Piedmont. In: Proc 5th biennial southern silvicultural research conference, 1988 Nov 1-3, Memphis, TN: Gen Tech Rep SO-74. New Orleans, LA: US Dept Agric, For Serv, Southern For Expt Stn, pp 603-611

Watson AG, Ford EJ (1972) Soil fungistais - a reappraisal. Annu Rev Phytopathol 9:327-348 (cited in Harvey et al. 1976) 
Weaver H (1959) Ecological changes in the ponderosa pine forest of the Warm Springs Indian Reservation in Oregon. J For 57(1): 15-20

West $\mathrm{O}(1965)$ Fire in vegetation and its use in pasture management with special reference to tropical and subtropical Africa. Comm Bur Pastures Field Crops Memo Pub 1/1965. Hurley, Berk, England, $53 \mathrm{pp}$

Weise DR, Wade DD, Johansen RW (1989) Survival and growth of young southern pine after simulated crown scorch. In: Proc 10th Conf on Fire and Forest Meteorology, 1989 April 17-21. Ottawa, Canada (in press)

Wells CG (1971) Effects of prescribed burning on soil chemical properties and nutrient availability. In: Proc prescribed burning Symp, 1971 Apr 14-16; Charleston, SC. Asheville, NC: US Dept Agric, For Serv, Southeastern For Expt Stn, pp 86-97

Wells CG, Campell RE, Debano LF et al. (1979) Effects of fire on soil. A state-of-knowledge review. Proc Nat fire effects workshop, 1978 Apr 10-14; Denver, CO. Gen Tech Rep WO-7. Washington, DC: US Dept Agric For Serv, 34 pp

Will GM (1959) Nutrient return in litter and rainfall under some exotic conifer stands in New Zealand. NZJ Agric Res 2:719-734

Woods RV (1981) The relationship between fire nutrient depletion, and decline in productivity between rotations in South Australia. In: Proc Australian Forest Nutrition Workshop Productivity in Perpetuity, 10-14 Aug 1981. Canberra, ACT (Abstr)

Wright E (1971) Mycorrhiza on ponderosa pine seedlings. Bull 13. Corvallis, OR: Oregon State Univ, $36 \mathrm{pp}$ (cited in Harvey et al. 1976)

Wright E, Tarrant RF (1957) Microbiological soil properties after logging and slash burning. Res Note 157. Portland, OR: US Dept Agric, For Serv, Pacific Northwest For Range Expt Stn, 5 pp

Zahner R (1989) Tree-ring series related to stand and environmental factors in South Alabama longleaf stands. In: Proc 5th biennial southern silvicultural research conference. 1988 Nov 1-3; Memphis, TN: Gen Tech Rep SO-74. New Orleans, LA: US Dept Agric, For Serv, Southern For Expt Stn, pp 193-197 